Historic, archived document

Do not assume content reflects current scientific knowledge, policies, or practices. 

$84 B$
$m 0.398$

UNITED STATES DEPARTMENT OF AGRICULTURE
BULLETIN No. 398
Contribution from the Bureau of Plant Industry
WM. A. TAYLOR, Chlef

By
N. C. DONALDSON, Scientific Assistant Office of Cereal Investigations

(In cooperation with the Montana Agricultural Experlment Station)

\section{CONTENTS}

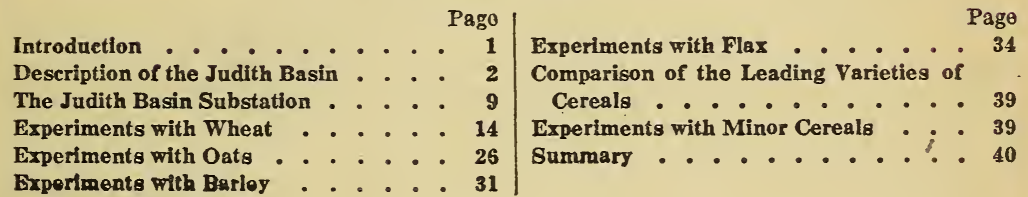





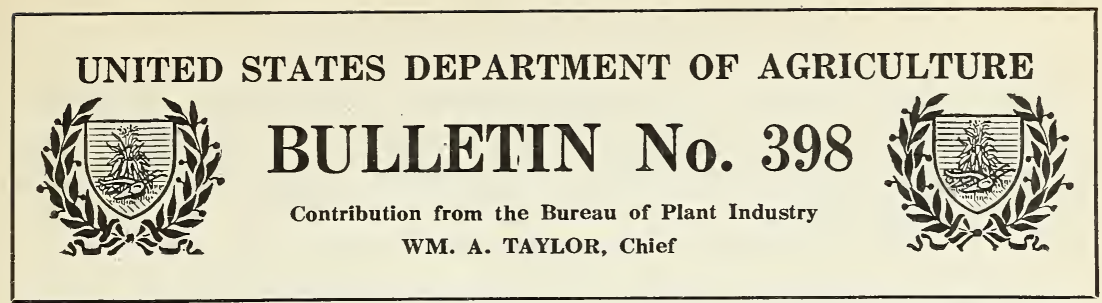

Washington, D. C.

\title{
CEREAL EXPERIMENTS AT THE JUDITH BASIN SUBSTATION, MOCCASIN, MONT.
}

\author{
By N. C. Donaldoson, \\ Scientific Assistant, Office of Cereal Investigations. \\ (In cooperation with the Montana Agricultural Experiment Station.)
}

Introduction...........................

CONTENTS.

Description of the Judith Basin...........

Page.

The Judith Basin substation. .............

Experiments with wheat ..................

Experiments with oats...................

1
2
9
14
26

Experiments with barley

Experiments with flax

Comparison of the leading varieties of cereals . $\quad 39$

Experiments with minor cereals........... $\quad 39$

26 Summary........................... 40

\section{INTRODUCTION.}

Experiments with cereals have been conducted cooperatively since 1908 at the Judith Basin substation, ${ }^{1}$ Moccasin, Mont., by the Office of Cereal Investigations of the Bureau of Plant Industry and the Montana Agricultural Experiment Station. The memorandum of understanding between the two parties specifies that-

The objects of these cooperative investigations shall be (1) to improve the cereals of the northern Plains region by introducing better varieties than those now grown, especially with regard to drought resistance, yield, quality, earliness, etc., and (2) to conduct such other experiments as may seem advisable for the accomplishment of the greatest possible good to the dry-land interests of the State.

This bulletin presents briefly the results of these investigations, together with such conclusions as they seem to warrant. All experiments here reported have been conducted under dry-land conditions.

i The Judith Basin substation was established in 1908 by the. Montana Agricultural Experiment Station in cooperation with the Bureau of Plant Industry. Prof. F. B. Linfield has been director of the State station since the substation was started. Prof. Alfred Atkinson, head of the agronomy department at the State station, has had direct charge of the substation for the State. Mr. J. M. Stephens has been superintendent of the substation since its establishment. - Mr. E. L. Adams was in charge of the experiments with cereals from 1909 to 1912. On his transfer to another station in May of the latter year, the writer of this bulletin was appointed agent of the Office of Cereal Investigations to take charge of the cooperative cereal work and on October 1, 1912, was appointed scientific assistant.

$48601^{\circ}-$ Bull. $398-16-1$ 


\section{DESCRIPTION OF THE JUDITH BASIN.}

The following rather detailed description of the Judith Basin and the conditions obtaining there allows comparison with other parts of the State of Montana where it is believed that the substation results are applicable.

TOPOGRAPHY.

The Judith Basin is an area of nearly 2,000,000 acres of tillable bench land lying in the western half of Fergus County, Mont. The basin, so called because it is nearly surrounded by mountains, is about 75 miles from east to west and 50 miles from north to south. The Little Belt Mountains form the southern and western boundaries. The Highwood Mountains and the Bad Lands, or breaks, of the Missouri River lie to the north. The North and South Moccasin, the Judith, and the Snowy Mountains form the eastern boundary. The basin is drained by the Judith River and its tributaries. Part of the land along the river and creek bottoms can be irrigated, but by far the larger part of the district is classed as dry land.

Until a few years ago the Judith Basin was a range country. The only land farmed was along the river and creek bottoms, while the bench lands were used to pasture great herds of oattle and sheep. Within the last 10 years practically all the tillable land in the Judith Basin has been brought under cultivation. Winter wheat is raised almost exclusively, although a few of the farmers are gradually working into a more diversified system of farming.

SOILS.

The soils of the Judith Basin are rather variable. The surface soil is a dark, heary clay loam of limestone origin, which varies in depth from a few inches to 3 feet. The soil when wet becomes rery sticky, and because of its adhesive character can be plowed only with a disk plow. Analysis of the soil shows that apparently it is quite rich in available plant food. The subsoil to a depth of 30 feet is composed of limestone gravel closely cemented together and is of such oharacter as will not allow the storage of water or the development of roots.

The composition of the soil at the substation, as determined by mechanical analysis, is shown in Table I. The stickiness of the soil is due largely to its high percentage of silt and clay, 40.7 and 24.3 per cent, respectively, in the surface foot.

TABLE I.-Composition of the soil at the Judith Basin substation, Moccasin, Mont., as determined by mechanical analysis.

\begin{tabular}{|c|c|c|c|c|c|}
\hline Constituents. & $\begin{array}{l}\text { First } \\
\text { foot. }\end{array}$ & $\begin{array}{l}\text { Second } \\
\text { foot. }\end{array}$ & Constituents. & $\begin{array}{l}\text { First } \\
\text { foot. }\end{array}$ & $\begin{array}{l}\text { Second } \\
\text { foot. }\end{array}$ \\
\hline $\begin{array}{l}\text { Fine gravel... } \\
\text { Coarse sand.. } \\
\text { Medium sand. } \\
\text { Fine sand.... }\end{array}$ & $\begin{array}{r}\text { Per cent. } \\
0.9 \\
2.7 \\
4.4 \\
13.3\end{array}$ & $\begin{array}{r}\text { Per cent. } \\
1.1 \\
2.3 \\
3.2 \\
10.4\end{array}$ & 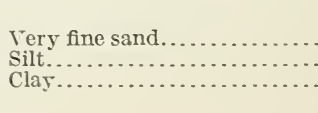 & $\begin{array}{r}\text { Per cent. } \\
13.4 \\
40.7 \\
24.3\end{array}$ & $\begin{array}{r}\text { Per cent. } \\
11.6 \\
33.3 \\
38.1\end{array}$ \\
\hline
\end{tabular}




\section{NATIVE GRASSES.}

In the original state the bench lands of the Judith Basin are covered with grass. The most important native grass is grama grass (Bouteloua oligostachya). Buffalo grass (Bulbulis dactyloides), western wheat-grass (Agropyron smithii, formerly $A$. occidentale), slender wheat-grass (Agropyron tenerum), and needle grass (Stipa comata and $S$. viridula) are also found, but are not as abundant as the grama grass. The grasses on the bench land make very good pasture, but seldom grow tall enough to be cut for hay.

\section{Climate.}

Before discussing crop yields or attempting to draw any conclusions it is necessary to have in mind the climatic factors affecting crop growth. The most important of these factors are (1) seasonal and annual rainfall, (2) the seasonal evaporation, and (3) temperature, with special reference to the length of the growing season as limited by the spring and fall frosts. With the exception of the rainfall records from 1898 to 1908, all data on these factors here presented have been obtained at the substation at Moccasin.

\section{PRECIPITATION.}

Table II gives the annual and average precipitation by months in the vicinity of Moccasin for the 18 years from 1898 to 1915, inclusive. Previous to 1909 the records were taken at Utica, 7 miles southwest of the substation. Since that time they have been taken at the substation by the Biophysical Laboratory of the Bureau of Plant Industry. The average annual precipitation for 18 years (Table II) is 16.66 inches. During this time the maximum precipitation in any one year was 23.76 inches (1909), and the minimum, 10.42 inches (1900).

The peculiar soil conditions existing at Moccasin and more or less throughout the Judith Basin make it nearly impossible to store any appreciable amount of moisture in the soil. The seasonal distribution of the rainfall, therefore, is of great importance. The growing season for spring grains at Moccasin extends from about April 1 to August 10. Since the precipitation that falls after the 1st of August has little effect on the yields of the crops, the growing season is considered as extending from April 1 to July 31. The average precipitation in this 4-month period during 18 years is 9.41 inches, or 56 per cent of the average annual precipitation. 
TABLE II.-Monthly, seasonal, and annual precipitation (in inches) in the vicinity of Moccasin, Mont., during the 18 years from 1898 to 1915, inclusive. ${ }^{1}$

[Data from the records of the United States Weather Bureau and of the Biophysical Laboratory of the Bureau of Plant Industry.]

\begin{tabular}{|c|c|c|c|c|c|c|c|c|c|c|c|c|c|c|}
\hline Yes & Jan. & Feb. & Mar. & Apr. & May. & June. & July. & Aug. & Sept. & Oct. & Nov. & Dec. & $\begin{array}{r}\text { Sea- } \\
\text { sonal. }\end{array}$ & Total. \\
\hline $\begin{array}{l}1913 \ldots \ldots \ldots \\
1914 \ldots \ldots \\
1915 \ldots \ldots\end{array}$ & $\begin{array}{r}0.70 \\
1.69 \\
.45 \\
.40 \\
.14 \\
.50 \\
.18 \\
.19 \\
.55 \\
1.34 \\
.55 \\
.90 \\
.09 \\
.58 \\
.88 \\
.89 \\
.47 \\
.76\end{array}$ & $\begin{array}{r}0.27 \\
.38 \\
.35 \\
.20 \\
.24 \\
.24 \\
.22 \\
.16 \\
.63 \\
.08 \\
.49 \\
.08 \\
.74 \\
.55 \\
.60 \\
.09 \\
1.35 \\
.08\end{array}$ & $\begin{array}{r}1.91 \\
.92 \\
.21 \\
.57 \\
.45 \\
1.11 \\
.79 \\
.62 \\
.43 \\
.61 \\
.98 \\
1.22 \\
.10 \\
.54 \\
.81 \\
.20 \\
1.12 \\
2.69 \\
\end{array}$ & $\begin{array}{r}1.12 \\
2.29 \\
2.85 \\
1.65 \\
1.12 \\
2.29 \\
1.14 \\
.75 \\
.16 \\
.43 \\
.61 \\
1.03 \\
1.31 \\
1.66 \\
1.43 \\
.79 \\
1.19 \\
1.43 \\
\end{array}$ & $\begin{array}{l}5.87 \\
3.33 \\
1.04 \\
3.82 \\
1.41 \\
1.82 \\
1.94 \\
1.97 \\
2.61 \\
3.21 \\
7.31 \\
1.34 \\
2.40 \\
2.98 \\
3.94 \\
2.64 \\
2.91 \\
2.12 \\
\end{array}$ & $\begin{array}{l}5.80 \\
1.22 \\
.44 \\
3.97 \\
3.28 \\
2.81 \\
1.73 \\
2.82 \\
2.66 \\
6.75 \\
2.45 \\
5.97 \\
1.69 \\
2.55 \\
.64 \\
4.77 \\
4.64 \\
3.97\end{array}$ & $\begin{array}{r}3.16 \\
2.57 \\
.70 \\
1.97 \\
1.84 \\
2.57 \\
3.25 \\
3.19 \\
.93 \\
3.51 \\
.20 \\
2.54 \\
1.10 \\
.50 \\
1.92 \\
1.12 \\
.64 \\
3.54\end{array}$ & $\begin{array}{r}0.67 \\
1.31 \\
2.20 \\
.90 \\
.67 \\
.81 \\
.42 \\
.27 \\
2.00 \\
1.47 \\
1.18 \\
4.21 \\
2.02 \\
6.34 \\
1.27 \\
.51 \\
.65 \\
.92 \\
\end{array}$ & $\begin{array}{r}0.47 \\
.28 \\
.82 \\
2.42 \\
.32 \\
2.42 \\
.12 \\
.83 \\
.99 \\
.73 \\
1.41 \\
4.47 \\
2.54 \\
1.37 \\
1.63 \\
1.01 \\
1.11 \\
2.65\end{array}$ & $\begin{array}{r}1.25 \\
1.15 \\
.86 \\
1.39 \\
.18 \\
.05 \\
.54 \\
.39 \\
.70 \\
.20 \\
6.27 \\
.49 \\
1.36 \\
1.94 \\
1.68 \\
1.63 \\
.74 \\
.85\end{array}$ & $\begin{array}{c}1.14 \\
.11 \\
.29 \\
2 \mathrm{~T} \\
2.04 \\
.44 \\
.50 \\
.50 \\
.42 \\
\mathrm{~T} \\
\mathrm{~T} \\
.30 \\
1.26 \\
1.76 \\
.14 \\
.93 \\
.64 \\
1.01\end{array}$ & $\begin{array}{c}0.59 \\
.88 \\
.21 \\
3.22 \\
.25 \\
.65 \\
.24 \\
\mathrm{~T} \\
.68 \\
\mathrm{~T} \\
.22 \\
1.21 \\
.48 \\
.68 \\
.06 \\
.38 \\
.21 \\
.66\end{array}$ & $\begin{array}{r}15.95 \\
9.41 \\
5.03 \\
11.41 \\
7.65 \\
9.49 \\
8.06 \\
8.73 \\
6.56 \\
13.90 \\
10.57 \\
10.88 \\
6.50 \\
7.69 \\
7.93 \\
9.32 \\
9.38 \\
11.06\end{array}$ & $\begin{array}{l}22.95 \\
16.13 \\
10.42 \\
20.51 \\
11.94 \\
15.71 \\
11.07 \\
11.69 \\
12.76 \\
18.33 \\
21.67 \\
23.76 \\
15.09 \\
21.45 \\
15.00 \\
14.96 \\
15.67 \\
20.68\end{array}$ \\
\hline $\begin{array}{l}\text { Average.... } \\
\text { Maximum .. } \\
\text { Minimum... }\end{array}$ & $\begin{array}{r}.62 \\
1.69 \\
.09\end{array}$ & $\begin{array}{r}.38 \\
1.35 \\
.08\end{array}$ & $\begin{array}{r}.85 \\
2.69 \\
.10\end{array}$ & $\begin{array}{r}1.29 \\
2.85 \\
.16\end{array}$ & $\begin{array}{l}7.31 \\
1.04\end{array}$ & $\begin{array}{r}3.23 \\
6.75 \\
.44\end{array}$ & $\begin{array}{r}1.96 \\
3.54 \\
.20\end{array}$ & $\begin{array}{r}1.55 \\
6.34 \\
.27\end{array}$ & $\begin{array}{r}4.47 \\
.12\end{array}$ & $\begin{array}{r}1.20 \\
6.27 \\
.05\end{array}$ & $\begin{array}{l}.64 \\
2.04 \\
\mathrm{~T}\end{array}$ & $\begin{array}{c}.59 \\
3.22 \\
\mathrm{~T}\end{array}$ & $\begin{array}{r}9.41 \\
15.95 \\
5.03\end{array}$ & $\begin{array}{l}23.76 \\
10.42\end{array}$ \\
\hline
\end{tabular}

1 Precipitation records previous to 1909 were taken at Utica, Mont., 7 miles southwest of the substation; in 1909 and since they were taken at the station.

$2 \mathrm{~T}=$ trace.

Table III gives the average monthly, annual, and seasonal precipitation at the Judith Basin substation in the nine years from 1907 to 1915, inclusive, the years during which experiments have been conducted at Moccasin. This table has been compiled from the

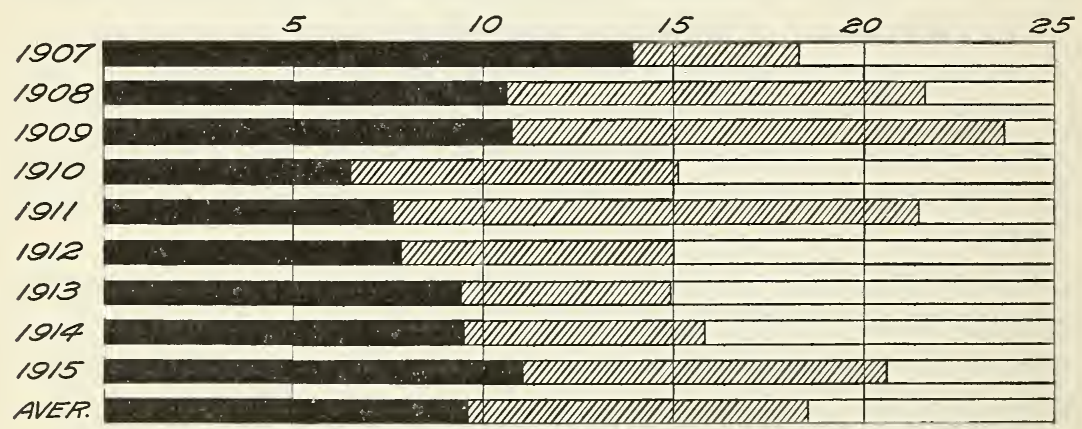

Fig. 1.-Diagram showing the annual and seasonal precipitation, in inches, at the Judith Basin substation, Moccasin, Mont., for nine years, 1907 to 1915, inclusive. Solid bars show the seasonal precipitation, while the total length of the bars shows the annual precipitation.

monthly and annual records given in Table II. The data for 1907 and 1908 are from the Weather Bureau records taken at Utica, 7 miles southwest of the station. The data for the remaining years are from the records of the Biophysical Laboratory of the Bureau of Plant Industry, taken at Moccasin. Figure 1 presents this data for each year in graphic form. 
TABLE III.-Average monthly, seasonal, and annual precipitation (in inches) at Moccasin, Mont., during the nine years from 1907 to 1915, inclusive.

[Data from the records of the United States Weather Bureau and of the Biophysical Laboratory of the Bureau of Plant Industry.]

\begin{tabular}{|c|c|c|c|c|c|c|c|c|c|c|c|c|c|c|}
\hline Nine years. & Jan. & Feb. & Mar. & Apr. & May. & June. & July. & Aug. & Sept. & Oct. & Nov. & Dec. & $\begin{array}{l}\text { Sea- } \\
\text { sonal. }\end{array}$ & Total. \\
\hline $\begin{array}{l}\text { Average....... } \\
\text { Maximum.... } \\
\text { Minimum.... }\end{array}$ & $\begin{array}{r}0.72 \\
1.34 \\
.09\end{array}$ & $\begin{array}{r}0.45 \\
1.35 \\
.08\end{array}$ & $\begin{array}{r}0.92 \\
2.69 \\
.10\end{array}$ & $\begin{array}{r}1.09 \\
1.43 \\
.43\end{array}$ & $\begin{array}{l}3.20 \\
7.31 \\
1.34\end{array}$ & $\begin{array}{r}3.72 \\
6.75 \\
.64\end{array}$ & $\begin{array}{r}1.67 \\
3.54 \\
.20\end{array}$ & $\begin{array}{r}2.06 \\
6.34 \\
.51\end{array}$ & $\begin{array}{r}1.86 \\
4.47 \\
.73\end{array}$ & $\begin{array}{r}1.68 \\
6.27 \\
.20\end{array}$ & $\begin{array}{l}0.67 \\
1.76 \\
1 \mathrm{~T}\end{array}$ & $\begin{array}{l}0.43 \\
1.21 \\
\mathrm{~T}\end{array}$ & $\begin{array}{r}9.69 \\
13.90 \\
6.50\end{array}$ & $\begin{array}{l}18.51 \\
23.76 \\
14.96\end{array}$ \\
\hline
\end{tabular}

${ }_{1} \mathrm{~T}=$ trace.

Since winter wheat usually is sown during August and September the record of seasonal precipitation for winter wheat should include these months. Table IV shows the annual and average precipitation in the calendar year and in the crop year for winter grains, the precipitation during the growing season for winter wheat, and the seasonal precipitation for spring small grains (Apr. 1 to July 31) in the eight years from 1908 to 1915, inclusive. In the crop year for winter wheat the figures are for the 12 months ended July 31 of the year indicated; that is, they show the precipitation affecting the crop of winter wheat harvested that year. In the same way, the precipitation during the growing season for winter wheat includes the three months (August to October) just preceding and following the seeding season and the four months (April to July) of the following spring and summer, thus covering the entire growth period of the crop. The winter precipitation (November to March, inclusive) may be easily determined by subtracting the figures for the growing season from those immediately preceding them in Table IV.

TABLE IV.-Annual and average precipitation (in inches) during the calendar year and in the crop year for winter grains and seasonal precipitation for spring grains at the Judith Basin substation in the eight years from 1908 to 1915, inclusive.

\begin{tabular}{|c|c|c|c|c|c|c|c|c|c|}
\hline Period. & 1908 & 1909 & 1910 & 1911 & 1912 & 1913 & 1914 & 1915 & $\begin{array}{l}\text { Aver- } \\
\text { age. }\end{array}$ \\
\hline Annual. & 21.67 & 23.76 & 15.09 & 21.45 & 15.00 & 14.96 & 15.67 & 20.68 & 18. 53 \\
\hline $\begin{array}{l}\text { (Aug. } 1 \text { to July } 31 \text { ). } 1 \\
\text { Growing periods for winter }\end{array}$ & 14.99 & 22.16 & 18.11 & 17.02 & 22.31 & 15.28 & 16.78 & 17.94 & 18.07 \\
\hline $\begin{array}{l}\text { grains }{ }^{2} \ldots \ldots \ldots \ldots \\
\text { Seasonal, for spring grains }\end{array}$ & 12.97 & 19.74 & 15.67 & 13.61 & 17.58 & 13.90 & 12.53 & 13.56 & 14.94 \\
\hline (Apr. 1 to July 31) & $10.5 \pi$ & 10.88 & 6.50 & 7.69 & 7.93 & 9.32 & 9.38 & 11.06 & 9.16 \\
\hline
\end{tabular}

1 The figures in each column are for the 12 months ended July 31 of the year indicated.

2 The figures in each column are for August to October of the preceding year (precipitation affecting fall growth) and April to July of the year indicated (precipitation affecting spring and summer growth).

To permit comparison of the precipitation at Moccasin with that in other portions of the State, the average annual precipitation at 25 different points in Montana, including Moccasin, is given in Table V. These data were obtained from the records of the United States Weather Bureau as published by the Montana Agricultural Experi- 
ment Station. ${ }^{1}$ In nearly all cases the arerage is for 16 years. 1s9s1913. inclusire.

Table $V$ shows that the precipitation at Moccasin is a little higher than in eastern Montana, but about the same as that of the central and western parts of the State. The locations of the stations for which data are giren are shown in figure 2.

TABIE T.-Average precipitation at 25 stations in Montana. including Mocoasin. jor the years indicated.

[Data from the records of the Tnited States Weather Bureau.]

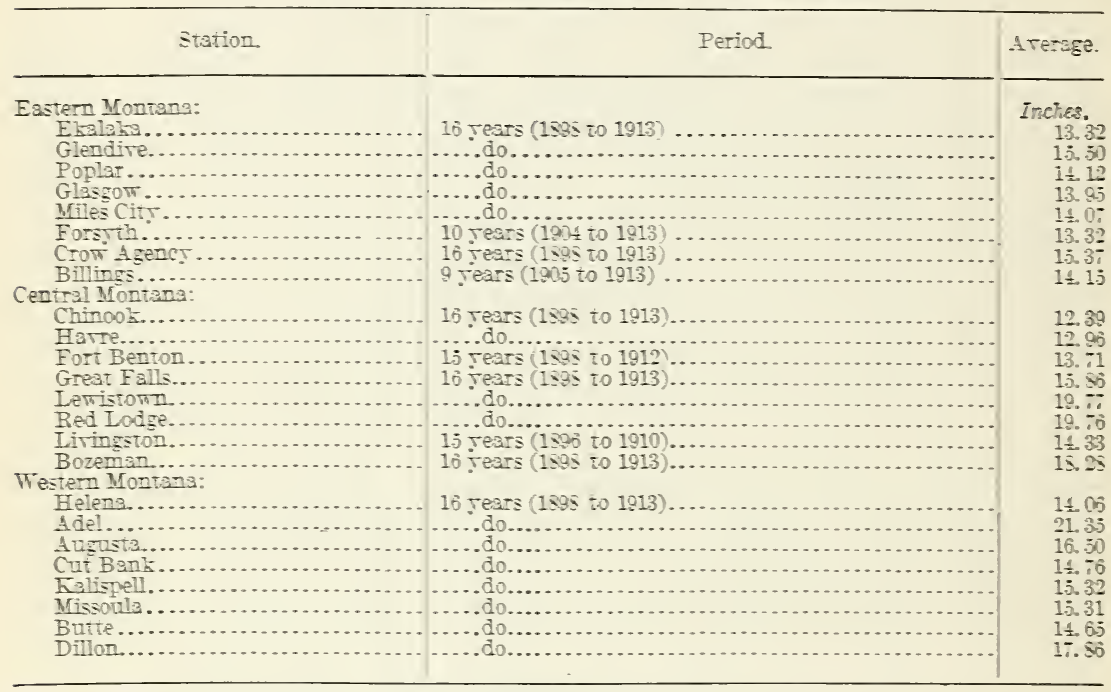

STMNAR:.

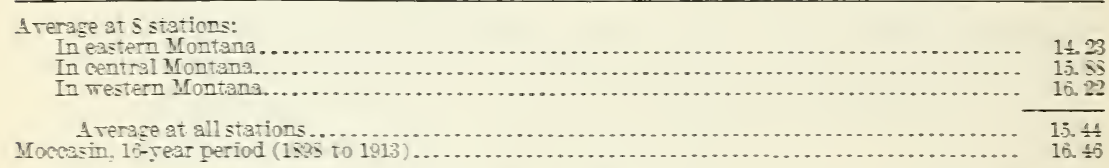

ETAPORATIOI.

Of the climatic factors that influence crop growth, eraporation is probabl next in importance to seasonal precipitation. Eraporation records hare been taken at Moccasin since 1909. The eraporation is determined from a free water surface, the method being the one usuallr emplored where the Biophrsical Laboratorr of the Bureau of Plant Industry is cooperating.?

Records are taken during six months. April to September, inclusire. In Table VI the eraporation and precipitation in these months are

1 Burke. Edmund, and Pincknes, R. M. Temperature records 159s-1913. An appendix to report on Montana climate. Mont. Agt. Exp. Sta. Bul. 99, p. 65-143. 1914.

: Brizgs. L. J.. and Belz, J. O. Dr. farming in relation to rainfall and ersporation. U. S. Dept. Agr.. Bur. Plant Indus. Bal. 1ss, p. 16-20. 1910. 
given for the seven years from 1909 to 1915, inclusive. This table also gives the total and average precipitation and evaporation in this period, with the ratio of the total precipitation to total evaporation.

TABLE VI.-Monthly precipitation and evaporation (in inches) from a free water surface at the Judith Basin substation, Moccasin, Mont., from April to September of each year from 1909 to 1915, inclusive.

[Data from the records of the Biophysical Laboratory of the Bureau of Plant Industry.]

\begin{tabular}{|c|c|c|c|c|c|c|c|c|c|c|c|c|c|c|c|}
\hline \multirow[b]{2}{*}{ Year. } & \multicolumn{2}{|c|}{ April. } & \multicolumn{2}{|c|}{ May. } & \multicolumn{2}{|c|}{ June. } & \multicolumn{2}{|c|}{ July. } & \multicolumn{2}{|c|}{ August. } & \multicolumn{2}{|c|}{ September. } & \multicolumn{2}{|c|}{ Total. } & \multirow[b]{2}{*}{ Ratio. } \\
\hline & $\begin{array}{l}\text { Pre- } \\
\text { cipi- } \\
\text { ta- } \\
\text { tion. }\end{array}$ & $\begin{array}{c}\text { Evap- } \\
\text { ora- } \\
\text { tion. }\end{array}$ & $\begin{array}{c}\text { Pre- } \\
\text { cipi- } \\
\text { ta- } \\
\text { tion. }\end{array}$ & $\begin{array}{l}\text { Evap- } \\
\text { ora- } \\
\text { tion. }\end{array}$ & $\begin{array}{l}\text { Pre- } \\
\text { cipi- } \\
\text { ta- } \\
\text { tion. }\end{array}$ & $\begin{array}{c}\text { Evap- } \\
\text { ora- } \\
\text { tion. }\end{array}$ & $\begin{array}{l}\text { Pre- } \\
\text { cipi- } \\
\text { ta- } \\
\text { tion. }\end{array}$ & $\begin{array}{c}\text { Evap- } \\
\text { ora- } \\
\text { tion. }\end{array}$ & $\begin{array}{c}\text { Pre- } \\
\text { cipi- } \\
\text { ta- } \\
\text { tion. }\end{array}$ & $\begin{array}{l}\text { Evap- } \\
\text { ora- } \\
\text { tion. }\end{array}$ & $\begin{array}{c}\text { Pre- } \\
\text { cipi- } \\
\text { ta- } \\
\text { tion. }\end{array}$ & $\begin{array}{c}\text { Evap- } \\
\text { ora- } \\
\text { tion. }\end{array}$ & $\begin{array}{c}\text { Pre- } \\
\text { cipi- } \\
\text { ta- } \\
\text { tion. }\end{array}$ & $\begin{array}{c}\text { Evap- } \\
\text { ora- } \\
\text { tion. }\end{array}$ & \\
\hline 1909 & 1.03 & 3.00 & 1.34 & 4.66 & 5.99 & 6.00 & 2.54 & 7.22 & 4. 21 & 7.06 & 4.47 & 4. 67 & 19.58 & 32.61 & $1: 1.6$ \\
\hline & & & 2 . & & 1.6 & 7. & 1. & & & & & 6.48 & & 14 & \\
\hline & 1.6 & 4.10 & 2.98 & 5.9 & 2.55 & 5.1 & .50 & 7. & 6.34 & 6.3 & 1.37 & 3.41 & 15.40 & 32.22 & $1:$ \\
\hline & 1.4 & 2 & 3.9 & & G & 6. & 1. & & 1. & & 1. & 3.42 & 10.83 & 28.77 & $1:$ \\
\hline & .79 & 3. 89 & 2. 64 & 4.2 & 4.77 & 4.90 & 1.12 & 6. & .5 & 7. & 1.01 & $\begin{array}{l}1 \quad 5.83 \\
\end{array}$ & 10.84 & 32.58 & $1: 3.0$ \\
\hline & 1.19 & 3 & 2. & & 4.64 & 4. & .6 & & .6 & & 1.11 & 5.10 & & & $1: 2.8$ \\
\hline & 1.43 & 4.70 & 2 & & 3.97 & 4.35 & 3.54 & & .9 & 6 . & 2.65 & 3.43 & 14.63 & 28.49 & $1: 1.9$ \\
\hline A verage & 1.28 & 3.81 & 2.92 & 4.86 & 3.04 & 5.49 & 1.82 & 6.78 & 2.27 & 6.87 & 2.11 & 4. 62 & 13.35 & 32.44 & $1: 2.4$ \\
\hline
\end{tabular}

The greatest evaporation in any one year, as shown in Table VI, was 40.14 inches (1910). While the seasonal precipitation (Apr. 1 to Sept. 30) in 1910 was not quite as low as in some of the other

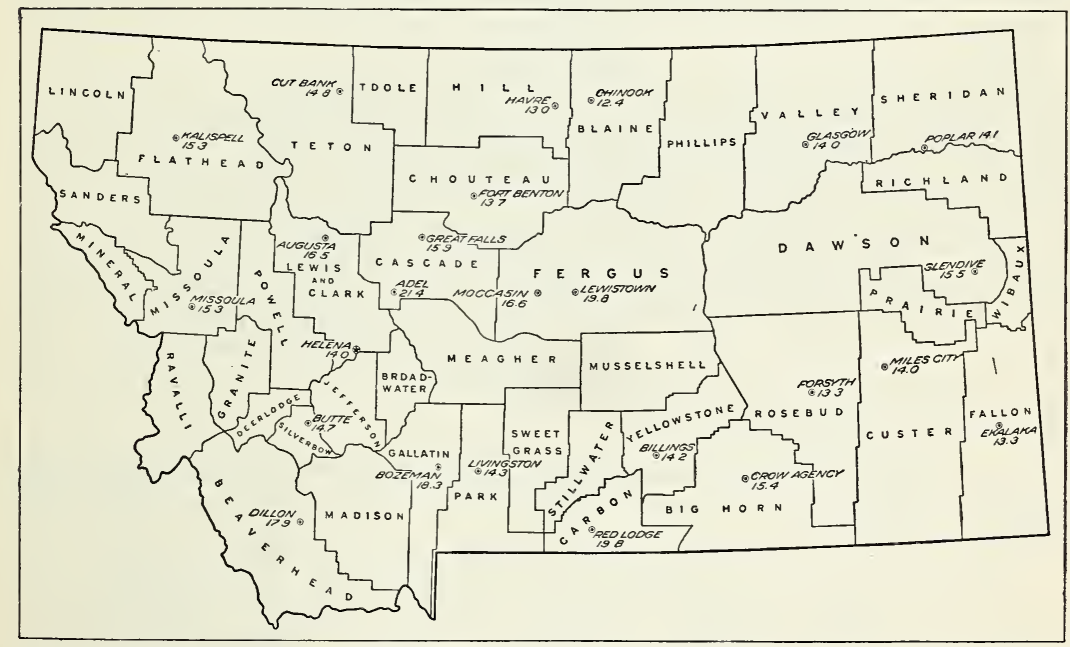

Fig. 2.-Map of Montana, showing the average annual precipitation (in inches) at the Judith Basin substation and at 24 other points in the State. These averages, for the most part, are for 16 years (1893 to 1915, inclusive).

years, the ratio between the precipitation and evaporation was wider than in any other year. The average ratio for the seven years is $1: 2.4$. A comparison of this ratio with the ratios for the different years gives a very fair basis for judging the seasonal conditions under which the experiments for each year were conducted. 
WIND.

Measurements of the wind velocity have been taken since 1910 at the Judith Basin substation by the Biophysical Laboratory of the Bureau of Plant Industry. The records are taken during six months, April to September, inclusive. The anemometer stands near the evaporation tank, at a height of about 2 feet above the surface of the ground. Table VII gives the average wind velocity from April to September in the six years from 1910 to 1915, inclusive.

TABLE VII.-Average wind velocity (in miles per hour) at the Judith Basin substation, Moccasin, Mont., by months, from April to September of each year from 1910 to 1915, inclusive.

[Data from the records of the Biophysical Laboratory of the Bureau of Plant Industry.]

\begin{tabular}{|c|c|c|c|c|c|c|c|}
\hline Year. & Apr. & May. & June. & July. & Aug. & Sept. & A verage. \\
\hline 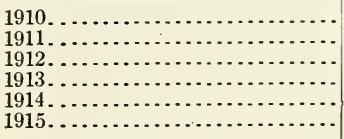 & $\begin{array}{l}9.0 \\
7.8 \\
6.6 \\
8.7 \\
6.3 \\
7.6\end{array}$ & $\begin{array}{l}6.8 \\
8.0 \\
7.6 \\
6.5 \\
7.5 \\
7.5\end{array}$ & $\begin{array}{l}6.3 \\
5.4 \\
5.7 \\
5.3 \\
6.4 \\
6.6\end{array}$ & $\begin{array}{l}5.9 \\
5.9 \\
5.1 \\
5.0 \\
5.5 \\
5.1\end{array}$ & $\begin{array}{l}6.0 \\
5.9 \\
6.4 \\
5.4 \\
6.0 \\
4.9\end{array}$ & $\begin{array}{l}4.0 \\
5.3 \\
6.7 \\
6.5 \\
7.2 \\
5.9\end{array}$ & $\begin{array}{l}\text { 6. } 33 \\
6.38 \\
6.35 \\
6.23 \\
6.48 \\
6.26\end{array}$ \\
\hline Average. & 7.7 & 7.3 & 6.0 & 5.4 & 5.8 & 5.9 & 6.35 \\
\hline
\end{tabular}

Table VII shows that April has the highest average wind velocity, 7.7 miles per hour. The average wind velocity decreases through May, June, and July, but increases again slightly in August and September. The 6-year average velocity in the six months is 6.35 miles per hour.

TEMPERATURE.

Table VIII gives the mean, maximum, and minimum temperatures at the Judith Basin substation by months from April to September of each year from 1909 to 1915, inclusive. The highest average mean temperatures occur in July and August, $63^{\circ} \mathrm{F}$., and the highest average maximum in August, $77^{\circ} \mathrm{F}$. Temperatures as high as $95^{\circ} \mathrm{F}$. are rare in the Judith Basin. When hot weather occurs it lasts for only a short time. Hot, drying winds are uncommon. In only one year since the station was started have hot winds done any damage to the growing crops.

TABLE VIII.-Mean, maximum, and minimum temperatures $\left({ }^{\circ} \mathrm{F}\right.$.) at the Judith Basin substation, Moccasin, Mont., by months, from April to September of each year from 1909 to 1915 , inclusive.

[Data from the records of the Biophysical Laboratory of the Bureau of Plant Industry.]

\begin{tabular}{|c|c|c|c|c|c|c|c|c|c|c|c|c|c|c|c|c|c|c|c|}
\hline \multirow[b]{2}{*}{ Year. } & \multicolumn{3}{|c|}{ April. } & \multicolumn{3}{|c|}{ May. } & \multicolumn{3}{|c|}{ June. } & \multicolumn{3}{|c|}{ July. } & \multicolumn{3}{|c|}{ August. } & \multicolumn{3}{|c|}{ September. } & \multirow{2}{*}{ 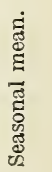 } \\
\hline & 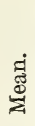 & 点 & 苦 & 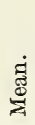 & 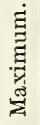 & 刭 & 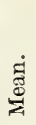 & 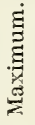 & 音 & 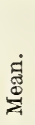 & 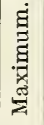 & 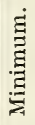 & 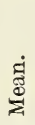 & 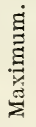 & $\underset{\Xi}{\stackrel{\Xi}{\Xi}}$ & 焉 & 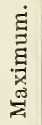 & 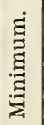 & \\
\hline $\begin{array}{c}309 \\
910\end{array}$ & $\begin{array}{l}35 \\
49 \\
38 \\
43 \\
43 \\
42 \\
50\end{array}$ & $\begin{array}{l}44 \\
65 \\
51 \\
55 \\
55 \\
56 \\
62\end{array}$ & $\begin{array}{l}25 \\
34 \\
26 \\
31 \\
31 \\
29 \\
37\end{array}$ & $\begin{array}{l}49 \\
51 \\
48 \\
50 \\
49 \\
51 \\
49\end{array}$ & $\begin{array}{l}60 \\
62 \\
59 \\
60 \\
63 \\
65 \\
59\end{array}$ & $\begin{array}{l}38 \\
41 \\
37 \\
37 \\
38 \\
37 \\
38\end{array}$ & $\begin{array}{l}60 \\
57 \\
52\end{array}$ & $\begin{array}{l}68 \\
74 \\
71 \\
74 \\
73 \\
69 \\
62\end{array}$ & $\begin{array}{l}47 \\
47 \\
47 \\
45 \\
48 \\
45 \\
42\end{array}$ & $\begin{array}{l}63 \\
68 \\
62 \\
61 \\
62 \\
68 \\
58\end{array}$ & $\begin{array}{l}74 \\
82 \\
77 \\
75 \\
76 \\
83 \\
69\end{array}$ & $\begin{array}{l}50 \\
53 \\
45 \\
47 \\
48 \\
51 \\
46\end{array}$ & $\begin{array}{l}65 \\
62 \\
58 \\
62 \\
65 \\
62 \\
66\end{array}$ & $\begin{array}{l}78 \\
75 \\
70 \\
76 \\
81 \\
77 \\
81\end{array}$ & $\begin{array}{l}50 \\
47 \\
47 \\
47\end{array}$ & $\begin{array}{l}59 \\
53 \\
50 \\
48 \\
55 \\
56 \\
19\end{array}$ & $\begin{array}{l}60 \\
72 \\
71 \\
59\end{array}$ & $\begin{array}{l}49 \\
41 \\
38 \\
35 \\
40 \\
40 \\
38\end{array}$ & $\begin{array}{l}56 \\
54\end{array}$ \\
\hline A verage & 43 & 55 & 30 & 49 & 61 & 38 & 58 & 70 & 46 & 63 & 76 & 49 & 63 & 77 & 48 & 53 & 65 & 40 & 55 \\
\hline
\end{tabular}


Table IX gives the dates of the last spring and first fall frosts and the number of days in the frost-free period in each year from 1909 to 1915, inclusive.

The longest frost-free period was 150 days, in 1909, and the shortest 82 days, in 1910. The latest frost in the spring was on June 4, in 1911. The average date of the last frost in the spring is May 20. The earliest frost in the fall in the seven years occurred on August 23, in 1910. The average date of the first frost in the fall is September 13. The average length of the frost-free period in the seven years is 116 days.

TABLE IX.-Dates of killing frosts, the last in spring and first in fall, with length of frost-free period in each year from 1909 to 1915, inclusive, at the Judith Basin substation, Moccasin, Mont.

[Data from the records of the Biophysical Laboratory of the Bureau of Plant Industry.]

\begin{tabular}{|c|c|c|c|c|c|c|c|}
\hline Year. & $\begin{array}{l}\text { Last in } \\
\text { spring. }\end{array}$ & $\begin{array}{l}\text { First in } \\
\text { fall. }\end{array}$ & $\begin{array}{l}\text { Frost-free } \\
\text { period. }\end{array}$ & Year. & $\begin{array}{l}\text { Last in } \\
\text { spring. }\end{array}$ & $\begin{array}{l}\text { First in } \\
\text { fall. }\end{array}$ & $\begin{array}{l}\text { Frost-free } \\
\text { period. }\end{array}$ \\
\hline \multirow{2}{*}{$\begin{array}{l}1909 \ldots \ldots \ldots \\
1910 \ldots \ldots \\
1911 \ldots \ldots \ldots \\
1912 \ldots \ldots\end{array}$} & \multirow{2}{*}{$\begin{array}{lr}\text { May } & 15 \\
\text { June } & 2 \\
\text { June } & 4 \\
\text { May } & 12 \\
\text { May } & 19\end{array}$} & \multirow{2}{*}{$\begin{array}{l}\text { Oct. } 12 \\
\text { Aug. } 23 \\
\text { Sept. } 15 \\
\text { Sept. } 15 \\
\text { Sept. } 9\end{array}$} & \multirow{2}{*}{\begin{tabular}{r||} 
Days. \\
150 \\
82 \\
103 \\
126 \\
112
\end{tabular}} & \multirow{2}{*}{$\begin{array}{r}1914 \ldots \\
\text { Average...... }\end{array}$} & $\begin{array}{l}\text { May } 12 \\
\text { May } 16\end{array}$ & $\begin{array}{l}\text { Sept. } 12 \\
\text { Sept. } 11\end{array}$ & $\begin{array}{r}\text { Days. }_{123} \\
118 \\
\end{array}$ \\
\hline & & & & & May 20 & Sept. 13 & 116 \\
\hline
\end{tabular}

THE JUDITH BASIN SUBSTATION.

LOCATION.

The Judith Basin substation is located 2 miles west of the town of Moccasin, in Fergus County, Mont., in the central part of the Judith Basin and about the geographical center of the State. The latitude is about $47^{\circ} \mathrm{N}$., and the longitude $109^{\circ} 45^{\prime} \mathrm{W}$. The substation farm is section 16, township 15 north, range 14 east. A branch of the Great Northern Railway from Great Falls to Billings passes through one corner of the station section.

\section{DESCRIPTION.}

The station farm consists of 640 acres. One corner of the farm is creek bottom and the remainder is level, tillable bench land. About 320 acres are under cultivation and the rest is used for pasture. The elevation at the substation is 4,300 feet. Figure 3 gives a view of the substation buildings in 1915 .

It is believed that the results obtained at Moccasin are applicable to the whole of the Judith Basin and in a general way to the 20,000,000 acres of diy land throughout the State, where the annual rainfall and its distribution are the chief factors limiting crop growth.

\section{SCOPE OF THE EXPERIMENTS.}

The experiments with cereals may be divided into two groups, plat tests and nursery tests. A general view of the plat and nursery is shown in figure 4. The plat experiments consist of varietal, 
date-of-seeding, and rate-of-seeding tests of winter and spring wheat, and spring oats, barler, and flax. In different years the number of rarieties under trial has raried from 75 to 125 . The number of plats in the date-of-seeding and rate-of-seeding tests has ranged from 40 to 60 , so that the total number of experiments has raried from 115 to 15.5 .

The nursery work at Moccasin corers two general lines: (1) The introduction and testing of new rarieties, and (2) experiments in the improrement of cereals. New rarieties are usually tested in nursery rows before being grown in plats. This makes possible the testing of a large number of rarieties with much less time and labor than would be necessary in larger plats.

The effort in the improrement work has been to select indiriduai heads representing desirable types. These selections usually are made from the rarieties that hare giren the best results in the plat

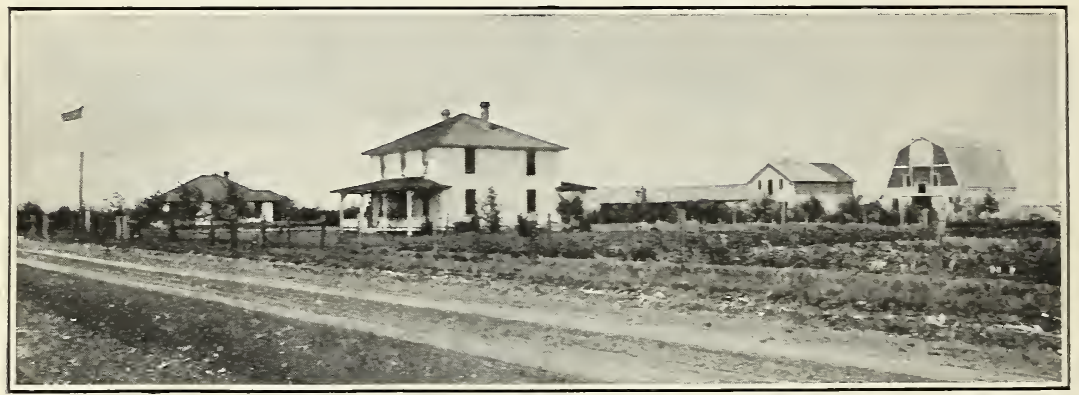

FTG. 3.-Buildings at the Judith Basin substation, Moccasin, Mont., in 1915. (From a photograph lent by the Office of Exhibits, U. S. Department of Agriculture.)

tests. These selections are multiplied and tested for yield and other desirable characters, such as length and stiffness of straw and freedom from shattering. The poor selections are discarded and the promising ones increased.

The number of rows has raried from 256 in 1909 to $\$ 40$ in 1911. Most of these are deroted to the improrement work. Since 1911 the number of rows has been reduced as the poor selections are discarded and the promising ones increased.

\section{EXPERIMENTAL METHODS.}

That portion of the substation farm used for plat work is dirided into blocks 132 feet wide and 617 feet long, which are separated by roads 1 rod wide. These blocks may be divided into tenth-acre, twentieth-acre, or fiftieth-acre plats, each 132 feet, or $\$$ rods, long.

\section{Plat Experimexts.}

SIZE OF PLATS.

All of the rarieties in 1908 and 1909 and nearly all in 1910 were grown on tenth-acre plats. In 1911 and 1912, because of the short- 
age of land, all crops except winter wheat were grown on twentiethacre plats. The tenth-acre plats are 2 rods wide and 8 rods long, with alleys $3 \frac{1}{2}$ feet wide between the plats and roads 1 rod wide between the blocks or series of plats. The twentieth-acre plats were 1 rod wide and 8 rods long, with 20 -inch alleys.

In 1913 some of the winter wheat varieties were grown on acre plats. These plats were 8 rods wide and 20 rods long. The springwheat varieties were grown in fiftieth-acre plats, and the rest of the spring cereals in tenth-acre plats. In 1914 and 1915, part of the winter-wheat varieties were grown in acre plats and the spring cereals in fiftieth-acre plats. The fiftieth-acre plats are 6 feet wide and 8 rods long, with 18 -inch alleys. This plat is actually one fiftyfifth of an acre in area, but as some moisture and plant food are drawn from the alleys, it seems fair to consider them as fiftieth-acre plats in computing acre yields.

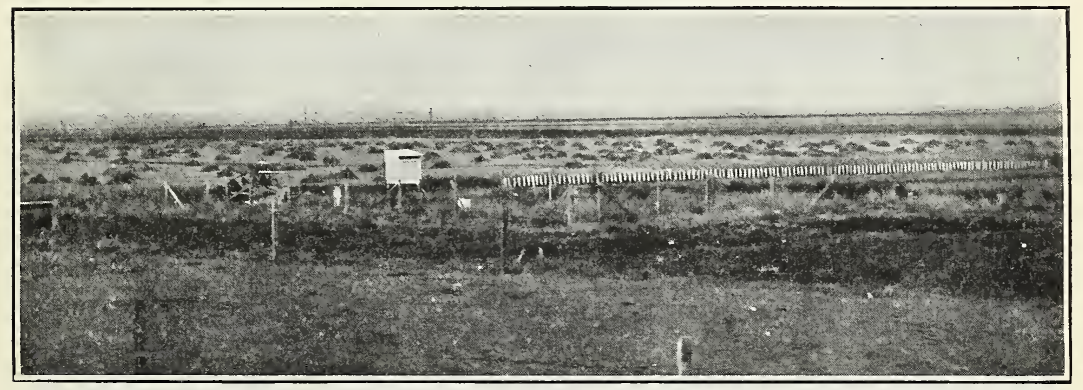

FiG. 4.-General view of the cereal experiment plats at the Judith Basin substation, Moccasin, Mont., 1910.

REPLICATION OF PLATS.

From 1908 until 1913 all varieties were grown in single tenth-acre or twentieth-acre plats. In every year except 1908 check plats of a standard variety were grown. In 1913 the spring-wheat varieties were grown in replicated fiftieth-acre plats, and in 1914 and 1915 all crops except the winter-wheat varieties in acre plats were grown in this way. A 6-foot drill is used and one drill width across the series ( 8 rods) covers one-fiftieth of an acre. As stated before, these plats are really one fifty-fifth of an acre in area, but in computing acre yields they are considered as one-fiftieth of an acre. In the system of plat replication in use at the Judith Basin substation five plats of each variety are grown. These plats are distributed throughout the space devoted to the test. In computing the yields of the varieties grown in replicated plats the average yield of the five fiftieth-acre plats of any one variety is obtained and the acre yield then computed.

PREPARATION OF THE I.AND.

With few exceptions all the varietal tests of cereals have been conducted on fallow ground. In 1908 the crops were sown on sod 
broken.in 1907 . In 1910 it was necessary to grow the barler rarieties on land that had been cropped to barley the prerious year. In 1911 and 1912 the flax rarieties were sown on ground that had produced a crop the year previous. In all other cases the rarietal experiments were conducted on fallow ground. A goad jab of breaking is shown in figure 5 .

Where the land was continuously cropped, the plowing was done in the spring and a goad seed bed prepared before sowing. The fallow ground was usually plowed in June or July, after weeds and

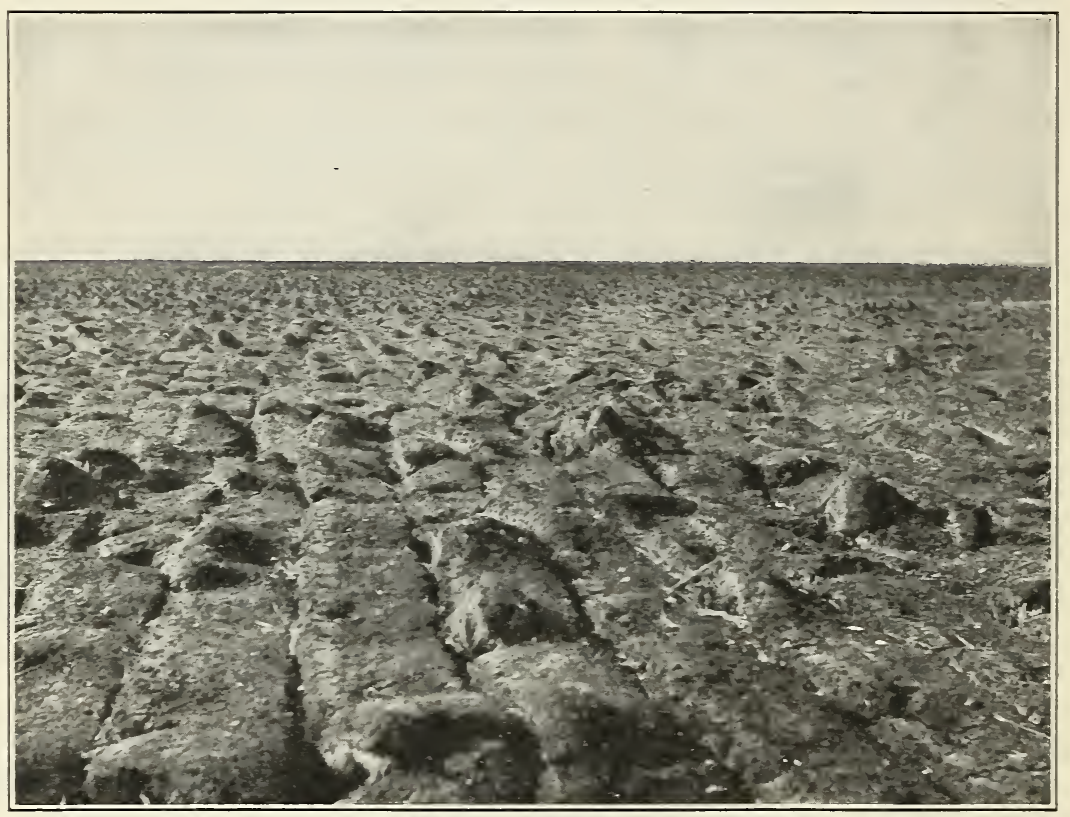

FIG. 5.-Sod land in the Judith Basin broken with a moldboard plow. The plow should have been followed by a heary roller to flatten the furrow slice and bring it in contact with the moist subsoil.

rolunteer grain were well started. Plowing was done with a disk plow to a depth of 7 to $S$ inches. It was found that if the land was worked down smoath after plowing there was likely to be considerable blowing of the soil during the winter; consequently, it has been the custom to leare the land rough until spring, when it is worked down with the disk and spike-tooth harrows to form a good seed bed.

In the preparation of the land an effort has been made to follow actual farm practices as closely as possible. In some cases it has been necessary to do some cultirating and hand weeding in order to keep the land uniform, but on the whole the plats hare not receired any more cultivation than would be giren under good farming conditions. 
TREATMENT OF CROPS.

The seeding has been done with an 8-foot double-disk and a 6-foot single-disk drill. On each drill the spouts were 6 inches apart. After seeding no cultivation has been given the plats. In some years it was necessary to cultivate the alleys and roads in order to kill the weeds. In the 18-inch alleys between the fiftieth-acre plats the weeds are pulled by hand, and no cultivation is necessary.

Harvesting is done with a binder. The grain is shocked on the plats and remains there until it is thrashed. The thrashing is done with a small thrasher with a 26 -inch cylinder. Since the varieties have been grown in the replicated plats, one plat of each variety has been carefully rogued and the crop from this plat thrashed in the small nursery thrasher. By this method it is possible to avoid the mixture that takes place in the larger thrasher and thus obtain pure seed of each variety.

CROP RECORDS.

The first notes taken after sowing are on the date of emergence. After this, notes are taken on the stand of the different varieties. Since all the varieties of any one cereal are seeded at the same rate and on the same date all stands are usually uniform, but any differences are noted. Any disease that may appear is noted, as is also the percentage of lodging. Records are kept of the dates of heading, ripening, and cutting of each variety.

\section{Nursery Experiments.}

The new varieties tested in the nursery are usually grown in 3-rod or 8-rod rows, depending on the quantity of seed available. In some cases it is possible to discard some of the varieties the first year, but usually they are grown two years. By that time it is possible to discard the poor varieties, while the most promising ones are increased.

In the improvement experiments the starting point is usually the head row. From the head row the good selections are grown in 3-rod or 8-rod rows, depending on the quantity of seed available. After being tested in 8-rod rows for two years it is usually possible to discard the poor selections. The more promising ones either are increased or continued in 8-rod rows. When they are increased they are usually grown in a hundredth-acre or fiftieth-acre plat for one or two years before being grown in the regular varietal test.

The selections in head rows are sown by hand. In all the other nursery work the seeding is done with a grain drill. In seeding the 3-rod and 8-rod rows alternate holes in the drill are closed and the rows sown 1 foot apart. The rows are harvested by hand and thrashed in the nursery thrasher. Complete notes are taken on all selections and varieties. 


\section{EXPERIMENTS WITH WHEAT.}

Wheat is the most important grain crop in Montana. For this reason the experiments with this crop have been more extensive than those with any of the other cereals. The experiments at the Judith Basin substation have included plat and nursery tests with both spring and winter wheats. Rate-of-seeding and date-of-seeding experiments with these cereals have also been conducted.

\section{WINTER WHEAT.}

In 1915 the production of winter wheat in Montana exceeded the production of spring wheat by nearly $3,000,000$ bushels. In the Judith Basin winter wheat is grown almost exclusively. In the eastern part of the State winter wheat can be grown only in favorable years. In some years good yields are produced, but there is likely to be winterkilling, so that it is not a sure crop. It is not possible to draw any definite line marking the boundary of the winter-wheat area in the State. At Forsyth, in the eastern part of Rosebud County, winter wheat can be grown successfully. East of Forsyth it can hardly be recommended, although it has been grown as far east as Glendive.

Where winter wheat can be grown successfully it yields more than spring wheat. It is thought that the results obtained from the winter-wheat tests at the Judith Basin substation are applicable wherever the crop can be grown in the State.

\section{Varietal Experiments in Field Plats.}

ANNUAL RESULTS.

The varietal experiments with winter wheat at Moccasin have included the varieties and strains that have given the best results in the winter-wheat section of the Great Plains area. The varieties have been grown on fallow ground each year. The plats have been either one-tenth acre or 1 acre.

In the fall of 1908, 15 varieties and strains of winter wheat were obtained from McPherson, Kans. These were sown September 18, which is too late for the best results in the Judith Basin. Owing to the late seeding there was considerable winterkilling. Six varieties sown 10 days later winterkilled entirely. In 1909 nine more varieties and strains were obtained from the Nephi (Utah) substation.

Table $\mathrm{X}$ gives the annual and average yields of 24 varieties of winter wheat that have been grown at the Judith Basin substation during periods of varying length in the seven years from 1909 to 1915, inclusive. In this table the varieties are grouped according to their relationships. Within the groups they are arranged alphabetically. 
TABLE X.-Annual and average yields of varieties of winter wheat at the Judith Basin substation, Moccasin, Mont., 1909 to 1915, inclusive.

\begin{tabular}{|c|c|c|c|c|c|c|c|c|c|c|c|}
\hline \multirow{3}{*}{ Group and variety. } & \multirow{3}{*}{$\begin{array}{l}\text { C. I. } \\
\text { No. }\end{array}$} & \multicolumn{10}{|c|}{ Yield per acre (bushels). } \\
\hline & & & & & & & & & & Average. & \\
\hline & & 1909 & 1910 & 1911 & 1912 & 1913 & a 1914 & a 1915 & $\begin{array}{l}\text { Three } \\
\text { years } \\
\text { (1909 to } \\
\text { 1911). }\end{array}$ & $\begin{array}{l}\text { Five } \\
\text { years } \\
\text { (1909 to } \\
1913) .\end{array}$ & $\begin{array}{c}\text { Seven } \\
\text { years } \\
\text { (1909 to } \\
1915) \text {. }\end{array}$ \\
\hline \multicolumn{12}{|c|}{ Crimean: } \\
\hline Alberta Red...... & 2979 & $\ldots$ & 37.0 & 38.5 & 16.0 & a34. 0 & 25.5 & 49.1 & $\cdots$ & .... & b 33.3 \\
\hline Armavir.......... & $135 \overline{5}$ & & 36.3 & 30.0 & & & & & $\cdots \cdots$ & $\cdots$ & $\ldots \ldots \ldots$ \\
\hline Beloglina..... & $\begin{array}{l}1543 \\
1544\end{array}$ & $\begin{array}{l}26.7 \\
25.0\end{array}$ & $\begin{array}{l}40.5 \\
32.7\end{array}$ & $\begin{array}{l}29.8 \\
34.8\end{array}$ & $\ddot{8.0}$ & & & $\cdots$ & $\begin{array}{l}32.3 \\
30.8\end{array}$ & $\cdots$ & ........... \\
\hline Crimean & 1432 & 23.7 & 34.0 & 40.3 & 12.7 & 31.8 & & & 32.7 & 28.5 & \\
\hline Do.. & 1433 & 15.3 & 32.4 & 34.0 & 9.5 & $\cdots \ldots$ & & & 27.2 & ........ & $\ldots$ \\
\hline Do.. & 1435 & 30.7 & 40.1 & 33.3 & 18.0 & a28. 0 & 23.8 & 49.5 & 34.7 & 30.0 & 31.9 \\
\hline Do... & 1436 & 24.2 & 34.2 & 32.7 & 11.5 & 30.0 & $\cdots \cdots$ & $\because \cdots$ & 30.4 & 26.5 & $\cdots$ \\
\hline Do... & 1437 & 27.5 & 37.4 & 40.2 & 14. 7 & a35. 3 & 22.7 & 51.0 & 35.0 & 31.0 & 32. 7 \\
\hline Do... & 1559 & 25.0 & 35. 3 & 40.0 & 10.0 & 35.0 & 22.4 & 49.2 & $33 . \underline{4}$ & 29.0 & 30.9 \\
\hline Kharkof.. & 1442 & 20.7 & 46.2 & 43.3 & 17.0 & a33. 1 & 25.5 & 49.0 & 36.7 & 32.0 & 33.5 \\
\hline Do........ & 1583 & 32.8 & 48.0 & 41.3 & 22.7 & a31. 1 & 24.5 & 49.4 & 40.7 & 35.2 & 35.7 \\
\hline Torgova... & 1539 & 25.0 & 30.4 & 29.2 & $\ldots . .$. & $\ldots \ldots$ & ..... & $\ldots \ldots$ & 28.2 & $\ldots \ldots . .$. & .......... \\
\hline Turkey ...... & 1532 & 18.3 & 29.4 & 33.7 & 14.0 & 29.0 & $\ldots .$. & $\cdots$ & 27.1 & 24.9 & a......... \\
\hline Do.. & 1571 & 23.3 & 41.6 & 37.7 & 21.5 & 29.7 & $\cdots$ & -. & 34.2 & 30.7 & - . . . \\
\hline Do... & 1576 & $m \cdots$ & 28.4 & 28.7 & $\cdots$ & $\cdots$ & $\cdots=$ & $\ldots .$. & 30 & $\cdots \cdots-$ & $\ldots$ \\
\hline Do... & 1558 & 21.7 & 43.7 & 43.7 & 22.7 & a32. 1 & 25.8 & 49.2 & 36.4 & 31.8 & 34.1 \\
\hline \multicolumn{12}{|c|}{ ( } \\
\hline Bacska. & 1562 & & 28.0 & 26.7 & & & & & & & \\
\hline Weissenberg. & 1563 & 24. 7 & 35.3 & 33.7 & & & $\ldots$ & & 31.2 & ‥ & \\
\hline \multicolumn{12}{|l|}{$\begin{array}{l}\text { Miscellaneous: } \\
\text { Currell........ }\end{array}$} \\
\hline $\begin{array}{l}\text { Currell.... } \\
\text { Ghirka Wi }\end{array}$ & 2906 & ...... & 22.6 & 31.7 & & & $\cdot$ & & & & - \\
\hline $\begin{array}{l}\text { Ghirka Winter.... } \\
\text { Koffoid. .......... }\end{array}$ & 1438 & . & 23.6 & 33.0 & & & & & & & .. \\
\hline Zimmerman..... & 2907 & $\ldots$ & $\begin{array}{l}19.0 \\
25.4\end{array}$ & $\begin{array}{l}34.2 \\
33.0\end{array}$ & & & & & $\ldots$ & & \\
\hline & & & & & & & & & & & \\
\hline
\end{tabular}

$a$ Yields from acre plats.

b A verage for six years only, 1910 to 1915 .

As stated previously, the yields in 1909 were lowered on account of winterkilling. The average survival on the winter-wheat plats in the spring of 1909 was 41 per cent. Wheat that was sown early did not suffer from winterkilling and yielded from 45 to 50 bushels per acre.

In 1910 and 1911 the seasonal precipitation was below the average, but as there was no hot weather and most of the seasonal rainfall came in May and June, good yields were obtained.

In 1912 the rainfall in May was above normal, while the precipitation for June was nearly 3 inches below normal. As a result the winter-wheat rarieties headed early. A local hailstorm on July 11, when the wheat was fully headed, reduced the yields about 50 per cent.

In 1913 conditions were about normal and an average crop was produced. In 1914 there was abnormally heary rainfall in May and June, followed by unusually hot, dry weather in July. This caused the wheat to ripen early. The yields were the lowest recorded at the station, with the exception of those produced in 1912, and the quality of grain was poor.

In 1915 the temperature during the growing season was below normal, while the rainfall was more than 2 inches above normal. $48601^{\circ}-$ Bull. $398-16-3$ 
The yields produced were the highest erer recorded at the station. Figure 6 shows the winter-wheat rarieties grown in replicated fiftiethacre plats in 1915 .

In the fall of 1912 and of each succeeding year the seren leading rarieties of winter wheat were seeded on acre plats. This change was made in order to test these rarieties on a large scale under actual field conditions and to hare seed of the best rarieties arailable for distribution. Table XI gires the annual and arerage vields of these seren rarieties on acre plats in the three rears, 1913, 1914, and 1915. The land where these rarieties were grown was not alwars in the best of tilth. The plan was to gire the land only such cultiva-

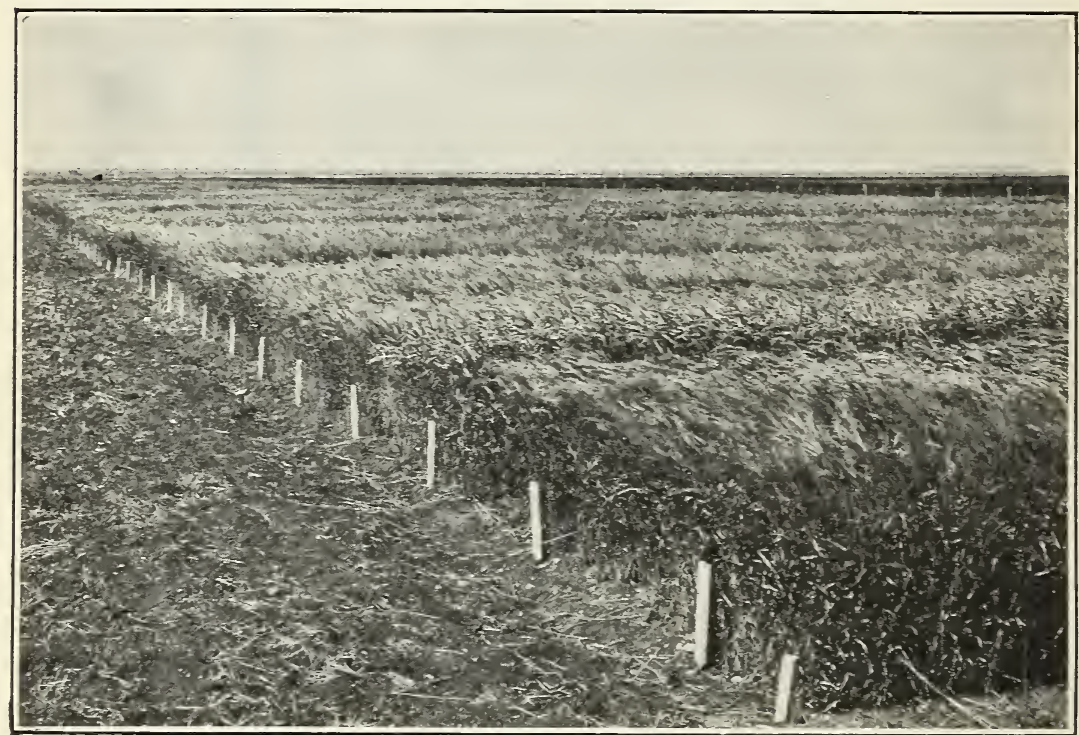

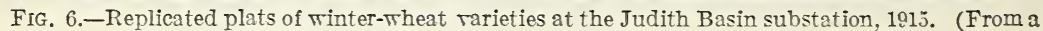
photograph lent by the Office of Exhibits, U. S. Department of Agriculture.)

tion as it would receire under arerage farm conditions. The yields from the acre plats were not as high as the rields of the same rarieties grown in the smaller plats.

TABLE XI.-Annual and average yield of seven varieties of winter wheat groun in acre plats at the Judith Basin substation, Moccasin, Mont., in the three years from 1913 to 1915, inclusive.

\begin{tabular}{|c|c|c|c|c|c|c|c|c|c|c|c|}
\hline \multirow[b]{2}{*}{ Variety. } & \multirow{2}{*}{$\begin{array}{l}\text { C. I. } \\
\text { No. }\end{array}$} & \multicolumn{4}{|c|}{ Yield per acre (bushels). } & \multirow[b]{2}{*}{ Variety. } & \multirow{2}{*}{$\begin{array}{l}\text { C. I. } \\
\text { No. }\end{array}$} & \multicolumn{4}{|c|}{ Yield per acre (bushels). } \\
\hline & & 1913 & 1914 & 1915 & $\begin{array}{l}\text { Arer- } \\
\text { age. }\end{array}$ & & & 1913 & 1914 & 1915 & $\begin{array}{l}\text { Arer- } \\
\text { age. }\end{array}$ \\
\hline $\begin{array}{r}\text { Alberta Red.. } \\
\text { Crimean..... } \\
\text { Do....... } \\
\text { Do........ }\end{array}$ & $\begin{array}{l}2979 \\
1435 \\
1437 \\
1559\end{array}$ & $\begin{array}{l}34.0 \\
25.0 \\
35.3 \\
35.0\end{array}$ & $\begin{array}{l}25.5 \\
23.8 \\
22.7 \\
22.4\end{array}$ & $\begin{array}{l}49.1 \\
49.5 \\
51.0 \\
49.2\end{array}$ & $\begin{array}{l}36.2 \\
33.5 \\
36.3 \\
35.5\end{array}$ & $\begin{array}{r}\text { Kharkof... } \\
\text { Do..... } \\
\text { Turkes.... }\end{array}$ & $\begin{array}{l}1 \pm 42 \\
15 \times 3 \\
1558\end{array}$ & $\begin{array}{l}33.1 \\
31.1 \\
32.1\end{array}$ & $\begin{array}{l}25.5 \\
24.5 \\
25.5\end{array}$ & $\begin{array}{l}49.0 \\
49.4 \\
49.2\end{array}$ & $\begin{array}{l}35.9 \\
35.0 \\
35.7\end{array}$ \\
\hline
\end{tabular}


Table XI shows that with the exception of the Crimean (C. I. No. 1435) there is little difference in the average yields of the different varieties. In 1913 the Kharkof (C. I. No. 1583) was grown on the outside plat in the series. There was considerable blowing of the soil during the fall and winter, and in consequence the stand and yield of this plat were reduced.

SUMMARY OF WINTER-WHEAT YIELDS.

Of the varieties that have been tested in plats, only six have been grown during the full period. One additional variety, the Alberta Red, has been grown for six years. The yields of these seven varieties are from acre plats in 1913, 1914, and 1915, and are not quite as high as they would have been had the varieties been grown in small plats under more favorable conditions.

Table $\mathrm{X}$ shows that of these varieties the Kharkof (C. I. No. 1583) has the highest average yield, 35.7 bushels per acre. This variety was also the highest in average yield in the 3-year and 5-year periods. A study of the yields of the Kharkof (C. I. No. 1583) shows that in 1909 and 1910 it was the highest yielding variety. In 1909 the stands of the varieties were reduced by winterkilling and the Kharkof came through with a higher percentage of survival than any of the others. In 1910, when the seasonal precipitation was the lowest recorded at the substation, the yield of the Kharkof wheat was considerably higher than that of any of the other varieties.

\section{Leading Varieties of Winter Wheat.}

Of the 24 varieties of winter wheat that are listed in Table $\mathrm{X}$ no less than 18 belong to the Crimean group. These wheats have bearded spikes with white glabrous glumes and hard red kernels. They were imported into this country from southern Russia and are now extensively grown in the central Great Plains and the Pacific Northwest. They are the most important varieties of winter wheat grown in Montana.

The Turkey is probably the best known variety, but the Kharkof and Crimean scarcely can be distinguished from it. The Kharkof, which has been the leading variety of winter wheat at the Judith Basin substation, is thought to be a superior strain of the Crimean group. It seems to be more hardy and to stand drought better than the other varieties, although there are not very large differences in the average yield of the Kharkof, Turkey, and Crimean varieties.

The Kharkof wheat has been increased for distribution among the farmers. This work was started in 1912 and since that time about 2,000 bushels have been sold from the station to farmers for 
seed. This seed has been distributed not only among the farmers in the Judiih Basin, but in other parts of the State as well. Reports obtained from farmers who are growing this variety in different parts of Montana indicate that they consider it better than other similar varieties. Some farmers claim that the Kharkof yields from 5 to 10 bushels more than any common strain of Turkey which they had been growing.

The average dates of seeding, heading, and maturity, the height, yield per acre of grain and of straw, and weight per bushel of the seven leading varieties of winter wheat are given in Table XII.

TABLE XII.-Average dates of seeding, heading, and maturity, days from seeding to maturity, height, yield of grain and straw, and weight per bushel of seven leading winterwheat varieties at the Judith Basin substation, Moccasin, Mont., in seven years, 1909 to 1915 , inclusive.

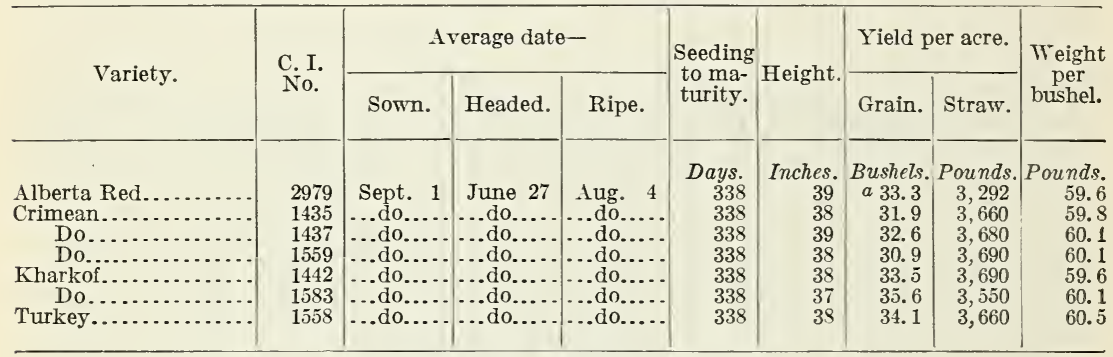

$a$ Average for six years, 1910-1915, inclusive.

Varietal Experiments ix Nursery Rows.

The nursery work with winter wheat at the Judith Basin substation has included the testing of new varieties and strains and the making and testing of selections. New varieties are usually grown in nursery rows, in order to determine their hardiness and something of their yielding powers before they are tested in plats.

In 1909 a large number of head selections were made from some of the best varieties. These were sown in head rows and the most promising were saved and sown in increase rows in 1910. Additional selections were made in 1910 and 1911, partly within the pure lines and partly from the mass varieties. In every case the selections appearing most promising the next year were saved and grown again.

In 1912 various selections were grown in hundredth-acre plats, 8-rod rows, and in head rows. The hail that year almost completely destroyed the winter-wheat nursery. No yields could be determined, though some plants survived the hail. From the records of previous years it was possible to determine which were the most promising selections. Some seed of these was obtained from surviving plants and sown that fall. Most of the selections had then been grown long enough to determine which were the most promising. Since that 
time most of the effort in the nursery work has been devoted to studying and increasing the selections already made rather than to the making of new ones.

At the present time nine selections are being grown in replicated plats in comparison with the mass variety, the Kharkof (C. I. No. 1583). Milling and baking tests are being conducted to determine their value in comparison with commercial varieties.

\section{Date-of-Seeding Experiments.}

Date-of-seeding tests with winter wheat have been conducted for six years. During the first three years, the Turkey (C. I. No. 1558) was used, while during the last three years the Kharkof (C. I. No. 1583) was sown. The dates included have ranged from August 1 to October 15. The results of these experiments have been rather variable, due, no doubt, to the variations in climatic conditions during August and September of the different years. In 1909 the earliest seeding, August 1, gave the best results. In that year there was considerable winterkilling in the late-sown plats. On the average, the best results have been obtained from plats sown between August 12 and September 20. It may happen in some years that there is not enough moisture in the soil in August and September to help germinate the wheat and give it a good start. When this condition occurs, late seeding is likely to be better than early seeding.

Table XIII gives the data that have been recorded in the date-ofseeding experiment. From this table it will be seen that in the six years the early September seeding (Sept. 1 to 7 ) has produced the highest average yield. There is little difference between the yields produced from seeding at this date and from seeding either about August 15 or September 15. It is probable that seeding between August 10 and September 20 will give good results. Wheat seeded after the later date is likely to get a poor start in the fall and therefore to winterkill.

TABLE XIII.-Annual and average yields obtained in a daie-of-seeding test with winter wheat at the Judith Basin substation, Moccasin, Mont., during the six years from 1909 to 1914; inclusive.

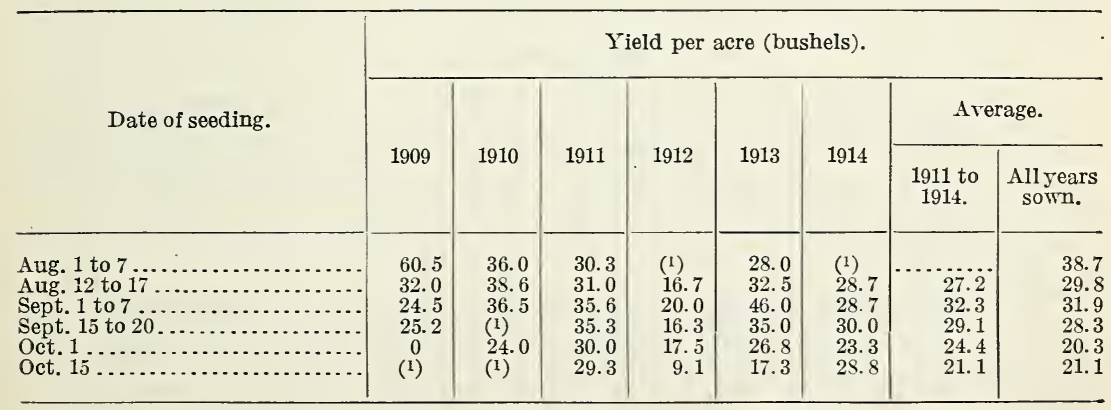

1 Not sown. 
Table XIII shows that the arerage yield of plats sown October 1 and October 15 is from 10 to 11 bushels per acre less than that of plats sown September 1 to 7.

In all the varietal tests at the Judith Basin substation an effort has been made to sow winter wheat early; that is, between August 10 and September 10. In 1908, the only year when there was much winterkilling, the seeding was late because the seed was not arailable earlier.

\section{Rate-of-Seedixg Experinents.}

Rate-of-seeding experiments with winter wheat were started in 1909 and conducted for six years. During the first three years, the Turkey (C. I. No. 1558) was used, while during the last three years the Kharkof (C. I. No. 1583) was sown. The rates of seeding ranged from 2 to 8 pecks per acre. Table XIV contains the data that have been obtained from these tests. This table shows that there is but little difference in the yields produced from the 3-peck and the 4-peck rates of seeding, the rates from which the highest yields hare been obtained.

Because of the free tillering of winter wheat it is not necessary to seed hearily in order to get a good stand. Seeding more than 4 pecks to the acre not only reduces the yield but also the quality of the grain. Three pecks is the rate usually sown by farmers in the Judith Basin and is the one at which all of the plats in the rarietal tests are sown.

TABLE XIV.-Annual and average yields obtained in a rate-of-seeding test with winter wheat at the Judith Basin substation, Moccasin, Mont., during six years, 1909 to 1914, inclusive.

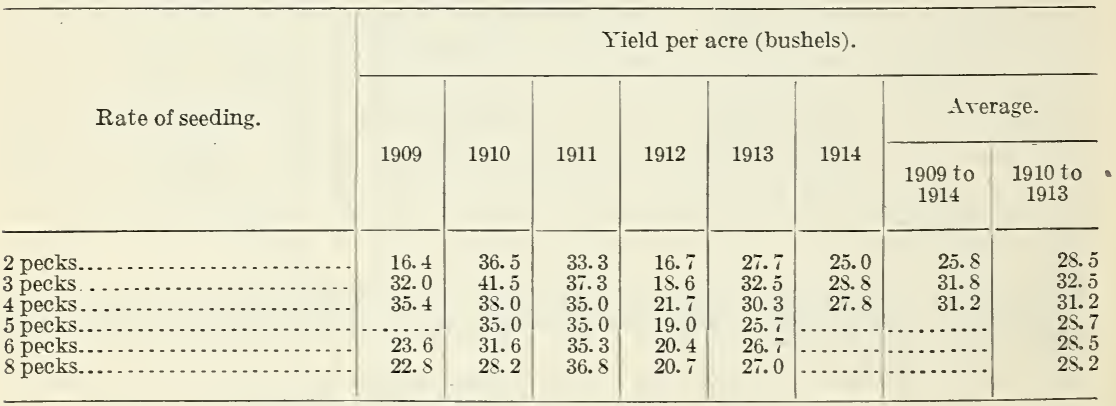

\section{SPRING WHEAT.}

Spring wheat is not as important a crop in Montana as winter wheat. In the Judith Basin the acreage of spring wheat is very small in comparison with that of winter wheat. In the eastern part of the State, where winter wheat is not a sure crop, spring wheat is of more importance.

The work with spring wheat at Moccasin has included field plat and nursery tests. The varieties tested have included those that hare given the best results in other dry-land districts of the Great Plains area. 
The spring-wheat varieties are sown at the rate of 4 pecks to the acre. The date of seeding has been governed by the climatic conditions. The best results are obtained from seeding as early as soil and weather conditions in the spring will permit. This date varies, of course, in different years.

\section{Varietal Experiments in Field Plats.}

ANNUAL RESULTS.

The varietal testing of spring wheat was started in 1908, when 20 varieties were grown. They were sown on ground that had been broken in 1907 and the seed bed was not in good tilth when the varieties were sown on May 5. The precipitation for June and July was below normal. As a result of the low precipitation and poor seed bed low yields were obtained from ail varieties.

In 1909 the varieties were sown on well-prepared fallow ground. The seeding was not done until May 12. The precipitation that year was above normal and good yields were obtained from all varieties.

In 1910 the varieties were sown on April 19. The precipitation was below normal; in fact, the seasonal precipitation for 1910 was the lowest recorded since the substation was established. The yields of all varieties were low, the average for the 23 varieties tested being 11.4 bushels per acre. A surprising fact in this year was that the spring common wheats outyielded the durum varieties. This result was contrary to the general opinion that the durum varieties are more resistant to drought than the spring common wheats. Low yields of durum varieties were obtained at several of the field stations in the Great Plains in 1910.

In 1911, because of a shortage of summer-fallowed land, the springwheat varieties were sown in twentieth-acre plats. The seeding was done April 20 in a well-prepared seed bed. The precipitation in May and June was about normal, but there was only 0.5 inch of rain in July. This was followed by excessive rainfall in August, which came in time to benefit the spring wheats. The total for the month was 6.34 inches. All varieties produced good yields and the quality of the grain was good.

In 1912 the precipitation for June was nearly 2 inches below normal. This was accompanied by rather hot weather. The spring-wheat varieties were just beginning to head on July 12, when they were completely destroyed by a severe hailstorm. While most varieties made some second growth no grain was produced.

A change was made in the method of testing the spring-wheat varieties in 1913. Instead of seeding them in single tenth-acre or twentieth-acre plats they were sown in fiftieth-acre plats and each variety replicated five times. Seeding was done on April 21 on wellprepared fallow ground. The crop that year was produced under normal conditions. 
In 1914 the spring wheat was again grown in replicated fiftieth-acre plats. The seeding was done on April 20. The precipitation in May and June was above normal. Hot, dry weather in July and August caused the wheat to ripen early and reduced the yields.

The year 1915 was marked by abnormally high rainfall and low temperatures during most of the growing season. The spring wheat was sown in replicated plats on April 9. The yields were the highest recorded at the substation.

\section{SUMMARY OF SPRING-WHEAT YIELDS.}

Table XV gives the annual and arerage yields of 25 varieties of spring wheat grown in plat tests at the Judith Basin substation during periods of varying length from 1908 to 1915, inclusire.

This table shows that the Galgalos (C. I. No. 2398) has produced the highest average yield both for the 4-year period (1908-1911) and the 7-year period (1908-1911 and 1913-1915). This wheat is a soft variety and is of less value for milling purposes than the hard wheats. The next highest yielding variety is a durum wheat, the Pelissier (C. I. No. 1584). This variety has a 7-year average yield of 27.2 bushels per acre, which is only 0.4 of a bushel less than the yield of the Galgalos. The durum group, as a whole, has vielded higher, on the arerage, than any other group.

TABLE XV.-Annual and average yields of 25 varieties of spring wheat grown in plat tests at the Judith Basin substation, Moccasin, Mont., during periods of varying length in seven years, 1908 to 1911 and 1913 to 1915, inclusive. ${ }^{1}$

\begin{tabular}{|c|c|c|c|c|c|c|c|c|c|c|c|}
\hline \multirow{3}{*}{ Group and variety. } & \multirow{3}{*}{$\begin{array}{l}\text { C. I. } \\
\text { No. }\end{array}$} & \multicolumn{10}{|c|}{ Yield per acre (bushels). } \\
\hline & & \multirow[b]{2}{*}{1908} & \multirow[b]{2}{*}{1909} & \multirow[b]{2}{*}{1910} & \multirow[b]{2}{*}{1911} & \multirow[b]{2}{*}{1913} & \multirow[b]{2}{*}{1914} & \multirow[b]{2}{*}{1915} & \multicolumn{3}{|c|}{ Average. } \\
\hline & & & & & & & & & $\begin{array}{c}1908 \text { to } \\
1911\end{array}$ & $\begin{array}{c}1908 \text { to } \\
1911, \\
1913 \text { to } \\
1915\end{array}$ & $\begin{array}{c}\text { For } \\
\text { period } \\
\text { grown. }\end{array}$ \\
\hline \multicolumn{12}{|l|}{ Durum group: } \\
\hline Arnautka. & 1493 & 10.0 & 36.7 & 10.0 & 25.0 & & & & 20.4 & & 20.4 \\
\hline Do.. & 1494 & 10.0 & 33.0 & 7.6 & 31.7 & & & & 20.6 & & 20.6 \\
\hline Belot & 1520 & 9.5 & 40 & 6.5 & 29.0 & 30.0 & 25.2 & 40.1 & 21.3 & 25.8 & 5.8 \\
\hline B & 1471 & 7.5 & 28 & 9.5 & 29.0 & & & & 18. 6 & & 6 \\
\hline G] & 1447 & 5.0 & 35.8 & 10.0 & 3 & & & & 20.3 & & 20.3 \\
\hline & 1440 & 5.0 & 37 & 8 & 33.0 & 30 & 23.0 & 40.7 & 21.1 & 25.5 & 25. \\
\hline & 1584 & 10.0 & 41 & 10. & 28 & 32 & 26.5 & 42.2 & 22.5 & $2 \overline{7} .2$ & 2 \\
\hline $\mathrm{Pe}$ & 1350 & 5. & 36 & 12. & 36.0 & 32.0 & 25.3 & 40.1 & 22.6 & 26.8 & G \\
\hline $\mathrm{Pl}$ & 3024 & 10.0 & 39 & 8. & 26.0 & & ....... & ...... & 20.9 & & 20.9 \\
\hline $\mathrm{Ta}$ & 1570 & 3. & 36 & 16. & 24.3 & & $\ldots .$. & & 20.0 & & 23. 0 \\
\hline V & 1445 & 7.5 & 32 & 6. & 26.0 & & 列 & & 18. 0 & & 18 \\
\hline Yellow Gh & 1414 & 15.0 & 39. & 8. & 27.7 & 32.8 & 25.0 & 39.2 & 22.5 & 26.8 & 26. \\
\hline \multicolumn{12}{|c|}{ 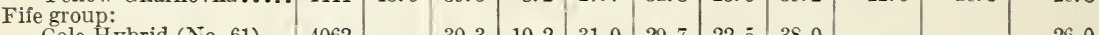 } \\
\hline $\begin{array}{l}\text { Cole Hybri } \\
\text { Ghirka Spr }\end{array}$ & $\begin{array}{l}4062 \\
1517\end{array}$ & $\ddot{3}$ & 30.3 & 10. 2 & 31.0 & 29.7 & 22.5 & 35.0 & 190 & 73 & 26.9 \\
\hline Glyndon ( & 1518 & 3.3 & & & 20.2 & 29.0 & 23.0 & 38.0 & 19.0 & 23.6 & \\
\hline 163) & 2873 & & & & 28.0 & 20.0 & 22.7 & 41.0 & & & 27.9 \\
\hline Marquis. & 3641 & 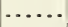 & & & $\ldots \ldots$ & 33.5 & 23.7 & & & & \\
\hline Power...... & 3697 & & & & & 25.7 & 24.1 & 41.0 & & & 31 \\
\hline \multirow{2}{*}{\multicolumn{11}{|c|}{ 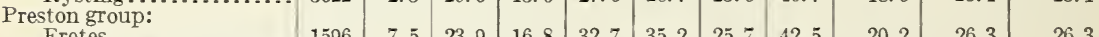 }} & 23.1 \\
\hline & & 7.5 & 23. & & & & & & & & \\
\hline Preston (M & 2958 & & 31. & 13.5 & 25.0 & 29.2 & 22.4 & 41.6 & & 20.0 & \\
\hline South Dakota & & ....... & 29.3 & 14.6 & 24.7 & & & & & & 2 \\
\hline \multicolumn{12}{|c|}{ Bluestem group: } \\
\hline $\begin{array}{l}\text { Haynes (Minn. No.169). } \\
\text { Haynes (Minn. No.51).. }\end{array}$ & $\begin{array}{l}2874 \\
3021\end{array}$ & 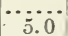 & $\begin{array}{l}29.7 \\
30.0\end{array}$ & $\begin{array}{r}9.1 \\
11.7\end{array}$ & $\begin{array}{l}18.7 \\
21.0\end{array}$ & & & & 17 & & $\begin{array}{l}19.2 \\
17.0\end{array}$ \\
\hline \multicolumn{12}{|l|}{ Miscellaneous: } \\
\hline Galga & 2398 & 7.5 & 40.2 & 18.5 & 31.3 & 30.7 & 24.5 & 40.5 & 24.4 & 27.6 & 27.6 \\
\hline & 2116 & & & & 1 & & 20. & & & & \\
\hline
\end{tabular}

1 The crop of 1912 was entirely destroyed by hail. 
Leading Varieties of Spring Wheat.

Of the 25 varieties of spring wheat that are listed in Table XV only 9 have been grown during the entire period. Of these, 5 belong to the durum group, 2 to the Fife group, 1 to the Preston group, and 1 is a miscellaneous variety. Table XVI gives the average dates of seeding, heading, and maturity, the average height and weight per bushel, and the average yields of grain and of straw from each variety during the seven years. From this table it will be seen that, as a group, the durum varieties yield higher than the other groups.

TABLE XVI.-Average dates of seeding, heading, and maturity, days from seeding to maturity, height, yield of grain and straw, and weight per bushel of nine leading springwheat varieties at the Judith Basin substation, Moccasin, Mont., during seven years, 1908 to 1911 and 1913 to 1915 , inclusive.

\begin{tabular}{|c|c|c|c|c|c|c|c|c|c|}
\hline \multirow{2}{*}{ Group and variety. } & \multirow{2}{*}{$\begin{array}{l}\text { C. I. } \\
\text { No. }\end{array}$} & \multicolumn{3}{|c|}{ Average date- } & \multirow{2}{*}{$\begin{array}{l}\text { Seed- } \\
\text { ing to } \\
\text { matur- } \\
\text { ity. }\end{array}$} & \multirow{2}{*}{ Height. ${ }^{1}$} & \multicolumn{2}{|c|}{ Yield per acre. } & \multirow{2}{*}{$\begin{array}{c}\text { Weight } \\
\text { per } \\
\text { bushel. }\end{array}$} \\
\hline & & Seeded. & Headed. & Ripe. & & & Grain. & Straw. ${ }^{1}$ & \\
\hline Durum group: & & & & & Days. & Inches. & Bush. & $L b s$. & $L b s$. \\
\hline Beloturka. & 1520 & Apr. 24 & July 16 & Aug. 24 & 122 & 43.5 & 25.8 & 3,108 & 59.6 \\
\hline Kubanka.. & 1440 & ...do..... & July 17 & Aug. 26 & 124 & 42. & 25.5 & 3,073 & 59.6 \\
\hline Pelis & 1584 & ...do..... & ...do..... & ,..do..... & 124 & 43 & $2 \overline{\mathrm{T}} .2$ & 2, & 60.0 \\
\hline Pererodka & 1350 & ...do..... & July 15 & Aug. 25 & 123 & 42.0 & 26.8 & 3,200 & 59.8 \\
\hline $\begin{array}{l}\text { Yellow Gharnovka. } \\
\text { Fife group: }\end{array}$ & 1444 & ...do..... & July 16 & Aug. 26 & 124 & 42. & 26.8 & 3,172 & 59.8 \\
\hline Ghirka Spring. & 1517 & ...do & July 17 & Aug. 25 & 123 & 37.5 & 23.7 & 2,576 & 59 \\
\hline Rysting.... & 3022 & ...do..... & July 20 & Aug. 27 & 125 & 39.0 & 23.1 & 2,796 & 59.2 \\
\hline $\begin{array}{l}\text { Preston group: } \\
\text { Frates...... }\end{array}$ & 1596 & ...do. & July 18 & Aug. 25 & 123 & 38.0 & 26.3 & 3,131 & 59.4 \\
\hline $\begin{array}{l}\text { Miscellaneous: } \\
\text { Galgalos... }\end{array}$ & 2398 & ...do... & July $\quad 16$ & Aug. 26 & 124 & 35.5 & 27.6 & 2,500 & 59.6 \\
\hline
\end{tabular}

1 Average for six years, 1909 to 1911 and 1913 to 1915, inclusive.

2 Average for five years, 1910, 1911, and 1913 to 1915, inclusive.

Durum wheat.-The learing durum wheat is the Pelissier (C. I. No. 1584). This variety has white glabrous glumes and black awns. The kernels are large, hard, and of a clear amber color. The other durum varieties that have been grown at Moccasin belong to the Kubanka group. They have glabrous yellow glumes and yellow awns.

Common wheat.-Among the common wheats that have been tried, the Galgalos (C. I. No. 2398) has produced the highest 7-year average yield. This variety is beardless, with brown pubescent glumes and rather large soft white kernels. While it yields well it is considered by millers to be poor in quality as compared with the hard wheats.

Of the Fife group, only two varieties have been grown during the full period. These are the Rysting and Ghirka. The Ghirka ripens about the same time as the durum varieties, while the Rysting is somewhat later. These two varieties have yielded from 3 to 4 bushels less than the durum wheats.

The Fretes (C. I. No. 1596) is the only variety belonging to the Preston group that has been grown during the seven years. This 
rariets rields a little more than the Fife rarieties. but not quite as much as the durums.

Table XIII gires the annual and arerage rields of the leading rariety in each of the groups for 1913, 1914, and 1915. From this table it will be seen that the Fretes leads, with the Pelissier second and the Marquis third. The Marquis has been grown at Moccasin for only three rears. During that time it has been among the highest rielders and is also of high milling quality. A riew of plats of the Marquis and Beloturka rarieties, the latter a durum wheat, is shown in figure 7 .

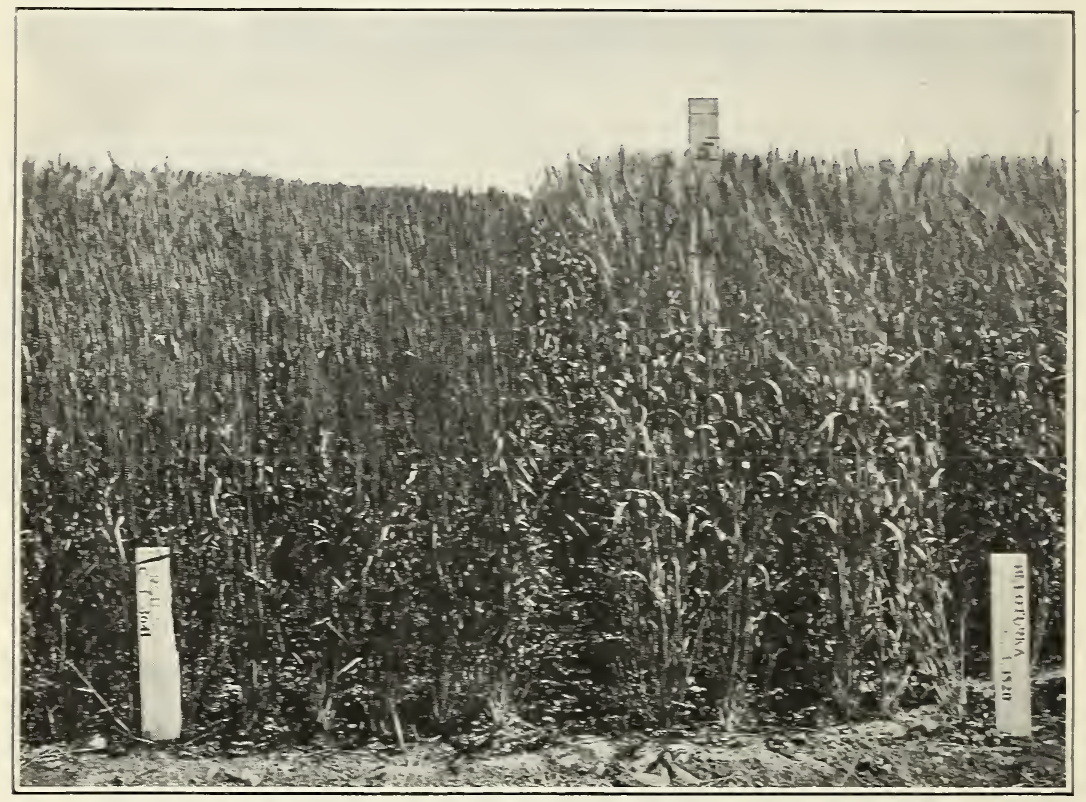

FIG. 7.-End view of plats of the Marquis and Beloturka wheats, the latter a durum rariety. (From a photograph lent bছ the Offlce of Exhibits, U.S. Department of Agriculture.)

TABLE MVII.-Annual and average yields of the leading variety in each group of spring wheat grovn at the Judith Basin substation. Moccasin. Mont.. during three years, 1913 to 1915 . inclusive.

\begin{tabular}{|c|c|c|c|c|c|c|c|c|c|c|c|}
\hline \multirow{2}{*}{ Group and rariets. } & \multirow{2}{*}{$\begin{array}{l}\text { C. I. } \\
\text { No. }\end{array}$} & \multicolumn{4}{|c|}{ Yield per acre (bushels). } & \multirow[b]{2}{*}{ Group and rariets. } & \multirow{2}{*}{$\begin{array}{l}\text { C. I. } \\
\text { No. }\end{array}$} & \multicolumn{4}{|c|}{ Yield per acre (bushels). } \\
\hline & & 1913 & 1914 & 1915 & $\begin{array}{l}\text { Aver- } \\
\text { age. }\end{array}$ & & & 1913 & 1914 & 1915 & $\begin{array}{l}\text { Arer- } \\
\text { age. }\end{array}$ \\
\hline $\begin{array}{l}\text { Durum group: } \\
\text { Pelissier...... } \\
\text { Fife group: } \\
\text { Marquis....... }\end{array}$ & $\begin{array}{l}1554 \\
3641\end{array}$ & $\begin{array}{l}32.0 \\
33.5\end{array}$ & $\begin{array}{l}23.5 \\
23.7\end{array}$ & $\begin{array}{l}42.2 \\
42.3\end{array}$ & $\begin{array}{l}33.6 \\
33.2\end{array}$ & $\begin{array}{c}\text { Preston group: } \\
\text { Fretes..... } \\
\text { Miscellaneous: } \\
\text { Galgalos... }\end{array}$ & $\begin{array}{l}1590 \\
2395\end{array}$ & $\begin{array}{l}35.2 \\
30.7\end{array}$ & $\begin{array}{l}25.7 \\
24.5\end{array}$ & $\begin{array}{l}42.5 \\
40.5\end{array}$ & $\begin{array}{l}34.5 \\
31.9\end{array}$ \\
\hline
\end{tabular}

Tarietal Experimexts in Nureert Rows.

The nursery work with spring wheat has been conducted along the same general lines as that with winter wheat. The work was started 
in 1909, when 206 varieties and selections were grown in 2-rod rows. In 1910 and 1911 head selections were made from the most promising varieties. In 1912 the spring-wheat nursery was completely destroyed by hail. A reserve supply of seed of a few of the selections was available and was sown in 1913. At the present time several selections have been increased and are being tested in fiftieth-acre plats.

\section{COMPARISON OF SPRING AND WINTER WHEATS.}

Table XVIII gives the annual and average yields of the leading varieties of spring and winter wheats during six years, 1909 to 1911 and 1913 to 1915, inclusive. The average yields are shown graphically in figure 8. Since the spring wheat was destroyed by hail in 1912, it was necessary to omit that year. The table shows that on the

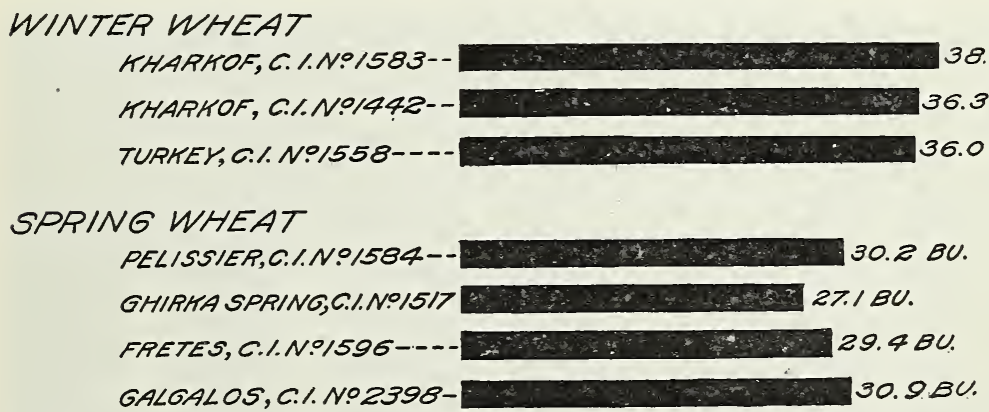

FIG. 8.-Diagram showing the average yields of winter and spring wheat varieties at the Judith Basin substation for six years, 1909 to 1911 and 1913 to 1915, inclusive.

average the winter wheats outyield the spring varieties by about 8 bushels per acre. Heads of representative varieties of the various groups of wheat are shown in figure 9.

TABLE XVIII.-Annual and average yields of leading varieties of winter and spring wheat grown at the Judith Basin substation, Moccasin, Mont., in the six years 1909 to 1911 and 1913 to 1915 , inclusive.

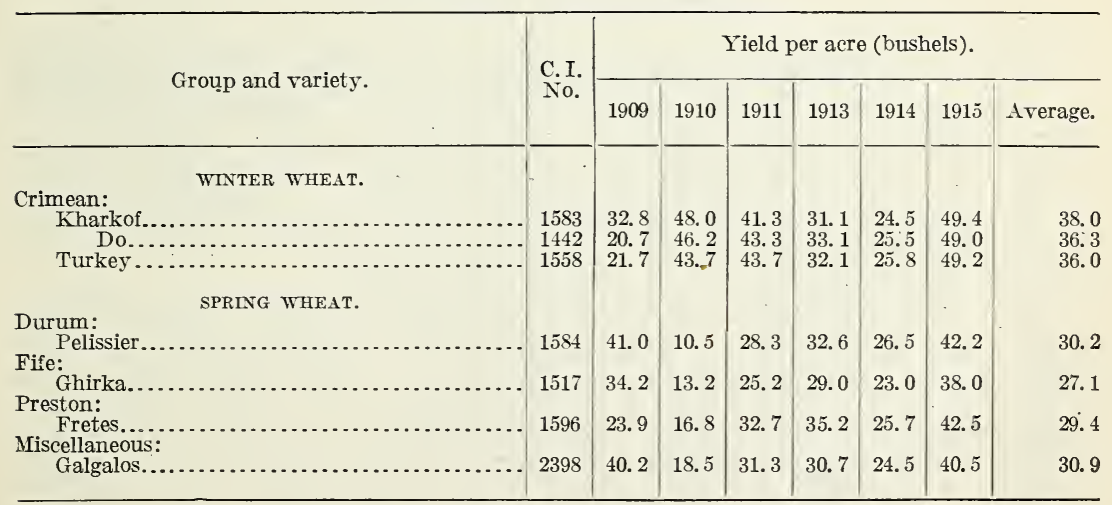


In 1909, when there was considerable winterkilling of the winter wheats, the spring wheats produced the larger yields. In 1910 and 1911, which were both years of drought, the winter rarieties outyielded the spring wheats. In 1913 and 1914 the yields were about equal. In 1915, when the rainfall was abnormally high, the winter wheats yielded 6 to 7 bushels more than the spring rarieties. For the six years the arerage yield of the best winter wheat is 7.8 bushels higher than that of the best spring wheat. It should be remembered that the rields of winter wheat in 1913, 1914, and 1915 are from acre plats, while those of spring wheat are from replicated fiftieth-acre plats.

The growing of winter wheat is to be recommended in the Judith Basin and generally in Montana wherever it is practicable, because the

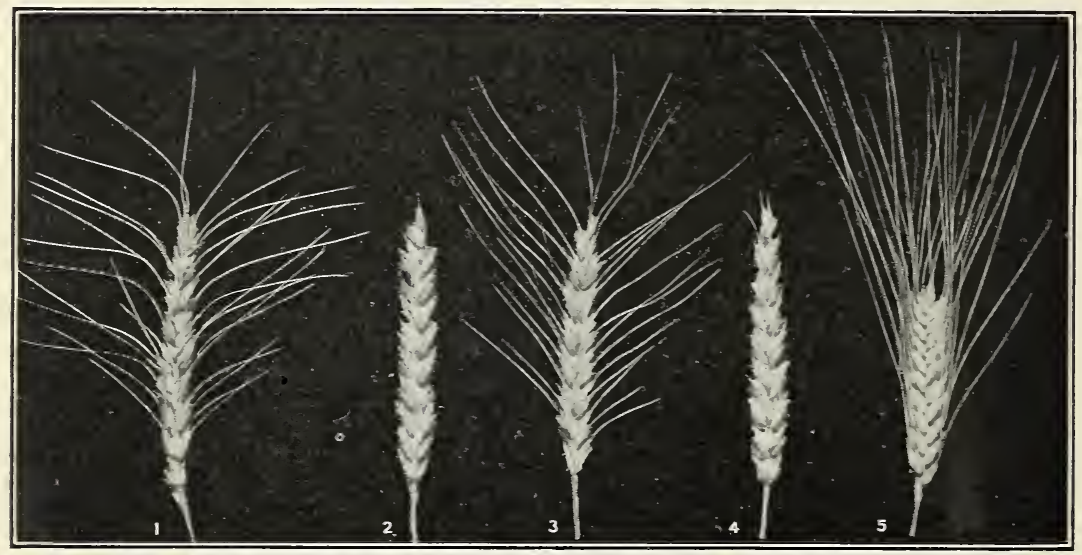

FIG. 9.-Heads of representative varieties of some of the important groups of wheat: 1, Turkey; 2, Fife; 3, Preston (bearded spring); 4 , bluestem; and 5, durum.

average yield is higher than that of spring wheat. In a rery dry year it may yield from three to four times as much as the spring rarieties.

\section{EXPERIMENTS WITH OATS.}

Next to wheat, oats are the most important cereal crop in Montana. In 1915 the area sown to oats in the State was estimated at 600,000 acres, with an arerage yield of 52 bushels per acre. Oats are not grown as a cash crop like wheat, but for feeding. The yields obtained at Moccasin are quite satisfactory and show that oats usually can be successfully grown on the dry lands of the State.

In the rarietal tests at Moccasin the small-kerneled early oats hare been sown at the rate of 4 pecks per acre. Seeding tests show but little difference in the results obtained from the 4-peck and 5-peck rates. In dry years, however, the lower rate of seeding gires the best yields. The larger kerneled varieties are sown at the rate of 5 pecks per acre. In a date-of-seeding test the best results were obtained 
from seeding as early in the spring as soil and climatic conditions permitted. In all the varietal work the effort has been to seed as early as possible.

\section{VARIETAL EXPERIMENTS IN FIELD PLATS.}

Table XIX gives the annual and average yields of 24 varieties of oats grown in plats at the Judith Basin substation from 1908 to 1915. Of the 24 varieties in this table, only 3 have been tested during the

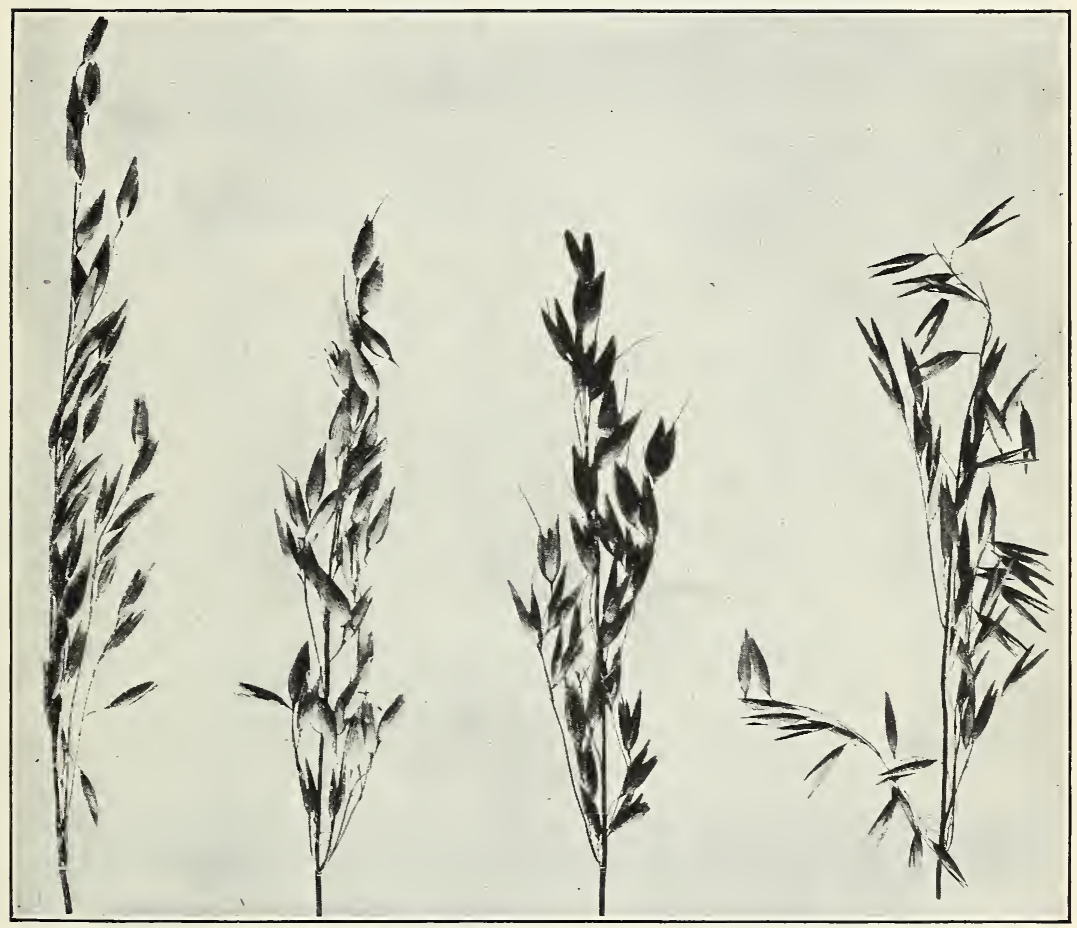

FIG. 10.-Heads of representative varieties of oats (left to right): 1, White Russian; 2, Siberian; 3 , Swedish Select; and 4, Sixty-Day.

entire period and only 14 of them are now being grown. Heads of representative varieties of oats are shown in figure 10.

In 1908 the oats were sown in a poor seed bed. Because of this and the drought in June and July, the yields were low. The year 1909 was one of abnormally high rainfall and good yields were obtained. In 1910 quite severe drought conditions prevailed during the growing season and the yields were low. It is noticeable that in this year the early oats outyielded the late varieties. In 1911 the oats which ripened before the heary August rains were the only ones to mature a crop. The rainfall during the month was 6.34 inches. This caused the late oats to make a second growth and they were not ripe when the first frost came. No crop was produced in 1912 be- 
cause of hail. In 1913 and 1914 crops were produced under nearly normal conditions, although in 1914 the dry weather in July reduced the yields somewhat. The only year in the period when the late oats outyielded the early ones was 1915, when the rainfall for the growing season was 2 inches above normal and the yields obtained were the highest recorded at the station.

TABLE XIX.-Annual and average yields of 24 varieties of oats grown in plats at the Judith Basin substation, Moccasin, Mont., for periods of varying length during the eight years from 1908 to 1915 , inclusive. ${ }^{1}$

\begin{tabular}{|c|c|c|c|c|c|c|c|c|c|c|c|}
\hline \multirow{3}{*}{ Group and variety. } & \multirow{3}{*}{$\begin{array}{l}\text { C. I. } \\
\text { No. }\end{array}$} & \multicolumn{10}{|c|}{ Yield per acre (bushels). } \\
\hline & & \multirow[b]{2}{*}{$190 \mathrm{~s}$} & \multirow[b]{2}{*}{1909} & \multirow[b]{2}{*}{1910} & \multirow[b]{2}{*}{1911} & \multirow[b]{2}{*}{1913} & \multirow[b]{2}{*}{1914} & \multirow[b]{2}{*}{1915} & \multicolumn{3}{|c|}{ Arerage. } \\
\hline & & & & & & & & & $\begin{array}{c}1908 \\
\text { to } \\
1911\end{array}$ & $\begin{array}{c}1913 \\
\text { to } \\
1915\end{array}$ & $\begin{array}{c}1908 \text { to } \\
1911,1913 \\
\text { to } 1915\end{array}$ \\
\hline Early: & & 10.0 & & & (2) & & & & & & \\
\hline Kherson.......... & 459 & 20.5 & 80.6 & 32.0 & 67.5 & 68.4 & 39.0 & 90.0 & 50.1 & 72.5 & $\ddot{5 s .3}$ \\
\hline Sixty-Day.. & 165 & 20.5 & 84.4 & 33.0 & 71.2 & 75.3 & 59.0 & 93.7 & 52.0 & 76.0 & 62.4 \\
\hline Sixty-Day selection. & 789 & & 01.1 & & 68.1 & 78.4 & 57.2 & 94.0 & & 76.5 & \\
\hline Do.................... & 625 & & & 29.5 & 58.7 & 73.4 & 56. 2 & 88.4 & & 72.7 & \\
\hline Do. & 626 & & & ....... & 53.7 & 80.0 & 56.0 & 95.6 & & 77.2 & \\
\hline $\begin{array}{l}\text { Midseason: } \\
\text { Banner. }\end{array}$ & 751 & & & & & 73.8 & & & & & \\
\hline Canadian... & $\begin{array}{l}101 \\
414\end{array}$ & 5.0 & 82.6 & 14.2 & $(2)$ & 7 & 46.3 & 99.0 & 25.4 & 73.0 & \\
\hline Danish. & 411 & 20.0 & 76.8 & 23.6 & $(2)$ & 56.2 & 47.3 & 100.0 & 30.1 & 67.8 & 46.2 \\
\hline Dakota No. $4 . .$. & 753 & & & & .... & $\cdots$ & 50.0 & .99 .0 & & & \\
\hline Early Mountain & 754 & 10.0 & 68.7 & 5. 8 & & & ...... & ...... & & & \\
\hline Garton White. . & 493 & .. & 67.8 & 18. 3 & $(2)$ & & & & & & \\
\hline $\begin{array}{l}\text { Golden Rain... } \\
\text { Lincoln......... }\end{array}$ & $\begin{array}{l}493 \\
738\end{array}$ & & & & $\left({ }^{2}\right)$ & & 51.0 & 100.0 & & & \\
\hline Red Algerian.... & 286 & 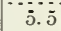 & 66.4 & 15.4 & $(2)$ & $\cdots$ & $\begin{array}{l}01.0 \\
\ldots . .\end{array}$ & 100.0 & $21 . \mathrm{s}$ & 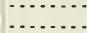 & $\cdots$ \\
\hline Red Siberian.. & 487 & ..... & 69.2 & 11.4 & $(2)$ & & & & & & \\
\hline Silvermine. & 714 & & ...... & $\cdots$ & ..... & ..... & 49.0 & 101.0 & & & \\
\hline Siberian......... & 741 & & & & & 70.0 & 46.3 & 98.7 & & 71.7 & \\
\hline Swedish Select. & 134 & 15.0 & 77.0 & 22.3 & $(2)$ & 53.1 & 50.0 & 108.0 & 28.6 & 70.4 & 46.5 \\
\hline Victory......... & 742 & & 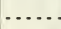 & 28.0 & $(2)$ & $\ldots .$. & 42.9 & 97.0 & ..... & & \\
\hline $\begin{array}{l}\text { Late: } \\
\text { Sparrowbill.... }\end{array}$ & 413 & & 690 & & $(2)$ & & & & & & \\
\hline White Russian... & 471 & $\begin{array}{r}10.0 \\
5.0\end{array}$ & $\begin{array}{l}09.0 \\
81.0\end{array}$ & $\begin{array}{r}20.1 \\
7.6\end{array}$ & $(2)$ & & & & $\begin{array}{l}20.0 \\
23.4\end{array}$ & $\ldots$ & $\cdots$ \\
\hline White Tartarian...... & 300 & 13.3 & $6 \overline{7} .3$ & 18.0 & (2) & $\ldots$ & 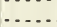 & . & 24.6 & (.......... & $\cdots$ \\
\hline Yellow Giant......... & 342 & 15. 0 & 65.0 & 8.6 & $(2)$ & & & & 22.1 & & \\
\hline
\end{tabular}

I Crop destroyed by hail in 1912.

2 Made second growth during rainy weather in August; not ripe when the first frost came.

In 1908, 1909, 1910, and 1913 the varieties were grown in unreplicated tenth-acre plats and in 1911 and 1912 in unreplicated twentiethacre plats. In 1914 and 1915 they were grown in fiftieth-acre plats replicated five times.

\section{LEADING VARIETIES.}

The rarieties of oats that hare been grown at Moccasin may be divided into three groups according to their date of maturityearly, midseason, and late. The early oats have giren the best arerage results.

Data on arerage dates of heading and of maturity, height, weight per bushel, and yield of grain and of straw for some of the leading 
varieties are given in Table XX. The average yields of these varieties are shown graphically in figure 11.

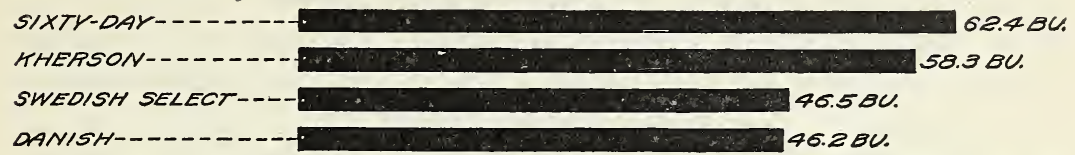

FIG. 11.-Diagram showing the average yields of the leading varieties of oats at the Judith Basin substation for seven years, 1908 to 1911 and 1913 to 1915, inclusive.

TABLE XX.-Average dates of seeding, heading, and ripening, days from seeding to maturity, height, weight per bushel, and yield of grain and straw of five leading oat varieties at the Judith Basin substation, Moccasin, Mont., during the seven years, 1908 to 1911 and 1913 to 1915 , inclusive.

\begin{tabular}{|c|c|c|c|c|c|c|c|c|c|c|}
\hline \multirow{3}{*}{ Group and variety. } & \multirow{3}{*}{$\begin{array}{l}\text { C. I. } \\
\text { No. }\end{array}$} & \multicolumn{3}{|c|}{ A verage date- } & \multirow{3}{*}{$\begin{array}{l}\text { Seed- } \\
\text { ing to } \\
\text { matu- } \\
\text { rity. }\end{array}$} & \multirow{3}{*}{ Height.a } & \multicolumn{3}{|c|}{ A verage yield per acre. } & \multirow{3}{*}{$\begin{array}{l}\text { Weight } \\
\text { per } \\
\text { bushel. }\end{array}$} \\
\hline & & & & & & & \multicolumn{2}{|c|}{ Grain. } & \multirow[b]{2}{*}{ Straw. $b$} & \\
\hline & & Sown. & Headed. & Ripe. & & & $\begin{array}{c}1908 \text { to } \\
1911 \\
\text { and } \\
1913 \text { to } \\
1915 .\end{array}$ & $\begin{array}{l}1913 \text { to } \\
1915 .\end{array}$ & & \\
\hline $\begin{array}{l}\text { Early yellow: } \\
\text { Sixty-Day .... } \\
\text { Kherson }\end{array}$ & $\begin{array}{l}165 \\
459\end{array}$ & $\begin{array}{r}\text { Apr. } 29 \\
\ldots \text { do...... }\end{array}$ & $\begin{array}{l}\text { July } 6 \\
\ldots \text {..do...... }\end{array}$ & $\begin{array}{l}\text { Aug. } 7 \\
\ldots \text {..do...... }\end{array}$ & $\begin{array}{r}\text { Days. } \\
100 \\
100\end{array}$ & $\begin{array}{r}\text { Inches. } \\
36.5 \\
36.3\end{array}$ & $\begin{array}{r}\text { Bush. } \\
62.4 \\
58.3\end{array}$ & $\begin{array}{r}\text { Bush. } \\
76.0 \\
72.5\end{array}$ & $\begin{array}{l}L b s . \\
2,250 \\
2,274\end{array}$ & $\begin{array}{l}L b s . \\
c 34.6 \\
c 34.6\end{array}$ \\
\hline $\begin{array}{l}\text { Midseason white: } \\
\text { Siberian } d . . . .\end{array}$ & 741 & Apr. 21 & Julष 21 & $A u$ & 114 & 48,0 & & 71 & 3.226 & 36.6 \\
\hline Swedish Select & 134 & Apr. 29 & July 17 & Aug. 16 & 110 & 42.0 & 46.5 & 70.4 & 2,714 & $e 37.0$ \\
\hline Danish.. & 441 & ...do..... & ...do..... & Aug. 18 & 111 & 39.0 & 46.2 & 67.8 & 2,513 & $e 32.3$ \\
\hline
\end{tabular}

a Average for six years, 1909 to 1911 and 1913 to 1915 , inclusive.

$b$ Average for five years, 1909 and 1910 and 1913 to 1915 , inclusive.

c Average for five years, 1910 and 1911 and 1913 to 1915, inclusive.

$d$ Average for three years, 1913 to 1915 , inclusive.

$e$ Average for four years, 1910 and 1913 to 1915 , inclusive.

\section{EARLY VARIETIES.}

The Sixty-Day and Kherson varieties are the only early oats that have been tested at Moccasin during the entire seven years. ${ }^{1}$ The Sixty-Day variety was introduced from southwestern Ruissia into the United States by the United States Department of Agriculture in 1901. The Kherson was imported from the same general locality a few years earlier by the Nebraska Agricultural Experiment Station. Plats of the Kherson and Sixty-Day oats at the Judith Basin substation are shown in figure 12 . The two varieties are practically identical. The straw is rather short and fine and the heads loose and spreading. The grain is yellow in color, small, long, and rather slender. The hull is thin, and under favorable conditions the weight per bushel is high. In the Judith Basin these varieties usually reach maturity in 95 to 105 days and are about 10 days earlier than the midseason varieties. At Moccasin the average yield of the SixtyDay is slightly larger than that of the Kherson. Two pure-line

1 For a more extended discussion of these varieties, see Warburton, C. W., Sixty-Day and Kherson oats, U. S. Dept. Agr., Farmers' Bul. 395, 27 p., 5 fig., 1910. 
selections from the Sixty-Day hare slightly exceeded the parent rariety in arerage yield in the rears they hare been grown.

There is some objection to these oats by farmers because of the rellow color and small size of the kernel. As oats are commonly grown in Montana for feed rather than to sell, the yellow color is not objectionable. Because of the thin hulls, these rarieties have a larger proportion of kernel to hull than the larger types of oats.

The Sixty-Day is being increased at the Judith Basin substation. About 2,000 bushels hare already been distributed throughout the dry-land areas of the State, and the results obtained seem to indicate that for these lands the Sixty-Day rariety is the best.

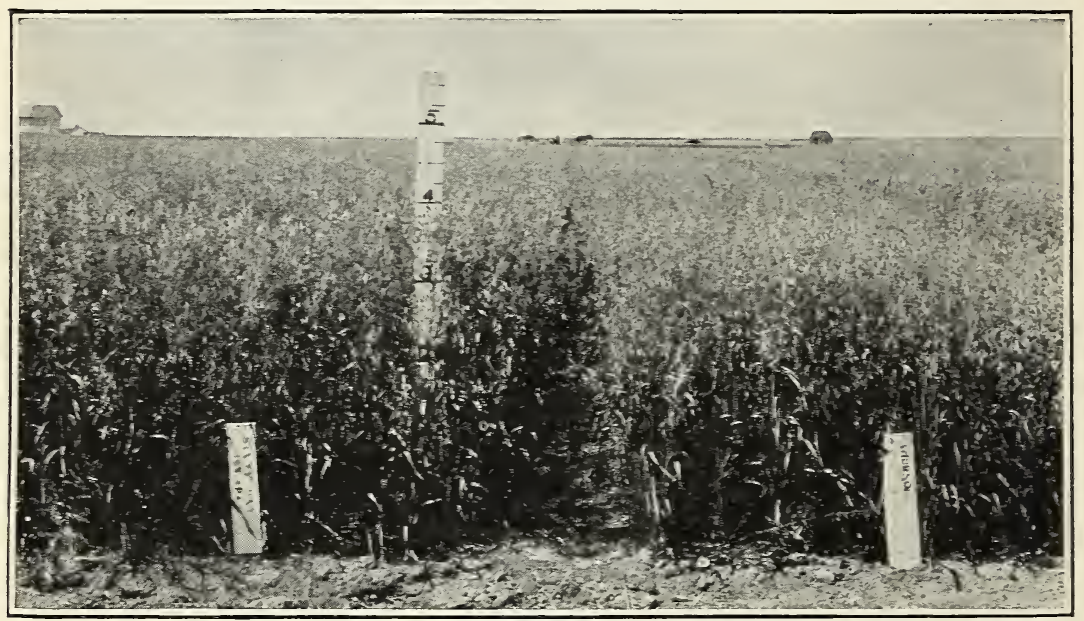

FIG. 12.-End view of plats of Sixty-Day and Kherson oats at the Judith Station substation, 1915. (From a photograph lent by the Office of Exhibits, U. S. Department of Agriculture.)

MIDSEASOX TARIETIES.

Of the rarieties of oats that hare been tested at Moccasin, 13 can be classed as midseason in maturity. The Swedish Select is the only one in this group that has been grown in the entire seren years. This variety has a 7-year arerage yield of 46.5 bushels, which is 15.9 bushels lower than the 7-year a rerage yield of the Sixtr-Day. Other typical varieties of this group are the Danish, Lincoln, and Silvermine. All these are more suitable for growing under irrigation than on the dry farms in Montana.

The varieties of the midseason group hare tall, coarse straw and large, rather broad grain. They are from a week to 10 days later in maturing than varieties of the early group.

LATE VARIETIES.

All the late rarieties which have been grown are side oats. The White Russian, White Tartarian, and other late rarieties hare not produced good rields at Moccasin except in 1909. In that year they 
did not yield more than the early and midseason varieties, while in less favorable years, such as 1908 and 1910, they were considerably lower in yield. The growing of these late side oats was discontinued in 1911. None of them can be recommended for growing on the dry lands in Montana.

\section{EXPERIMENTS WITH BARLEY.}

Barley is not as important a crop in Montana as wheat or oats. The estimated area sown to barley in the State in 1915 was 80,000

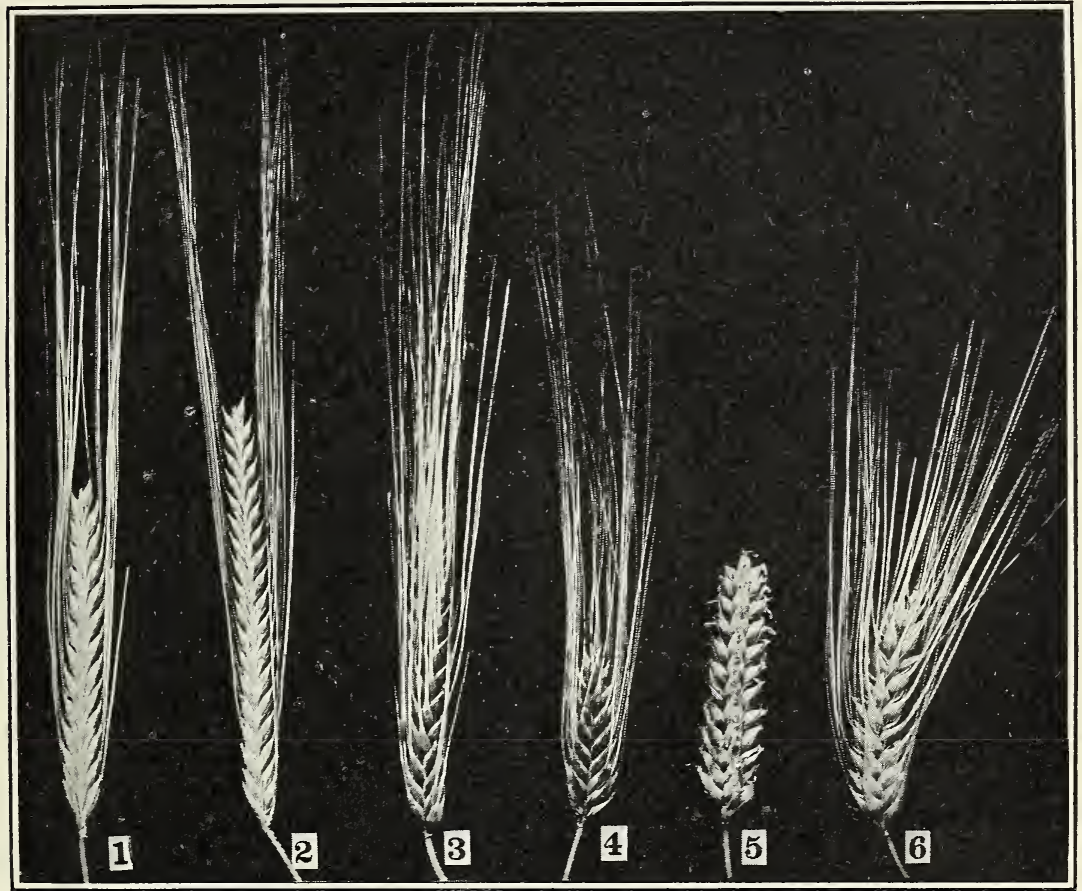

Fig. 13.-Heads of representative varieties of barley: 1, White Smyrna, and 2, Hannchen, 2-rowed hulled varieties; 3, Coast, and 4, Mariout, 6-rowed hulled varieties; and 5, Nepal, and 6, Himalaya, 6-rowed naked varieties.

acres, about 13 per cent of the oat acreage and 6 per cent of the wheat acreage of that year. The results of the experiments at Moccasin show that good yields of barley can be obtained on dry land and that the crop is a profitable one. Barley is grown chiefly for feeding purposes.

The varietal tests at Moccasin have included both the hulled and the naked, or hull-less, varieties. As with the other spring cereals, early seeding has given the best results. The hulled varieties are seeded at the rate of 5 pecks per acre and the naked varieties at the rate of 4 pecks.

\section{VARIETAL EXPERIMENTS IN FIELD PLATS.}

Seven varieties of barley were grown in 1908. Because of the poor seed bed and drought, low yields were obtained. In 1909 fairly good 
rields were obtained from all rarieties. In 1910 six more rarieties were added to the test. Because of the shortage of summer-fallowed land it was necessary to grow the rarieties on the ground used for testing barles in 1909. The land was plowed early in the spring and the seeding was done on April 20. The resulting vields were low. In 1911 the hot, dry weather in Julr reduced the rields, and in 1912 all rarieties were destroyed br hail. In 1913 good yields were obtained from all rarieties. The hot, dry weather during Juls. 1914. caused the rarieties to ripen early and the quality of the grain was poor. The rields obtained in 1915 were the highest recorded at the station.

The barley rarieties were grown in unreplicated tenth-acre plats in 1905, 1909, 1910, and 1913 and in unreplicated twentieth-acre plats in 1911 and 1912. In 1914 and 1915 they were grown in fiftieth-acre plats, replicated fire times.

Table XXI gires the annual and arerage vields of the barley varieties that hare been tested at Moccasin from 190 s to 1915. Of the 19 rarieties listed in this table, 9 belong to the 2-rowed hulled group, 5 to the 6-rowed hulled group, 2 to the 2-rowed naked group, and 3 to the 6-rowed naked group. Only 3 of the 19 rarieties hare been grown in all seren rears and only 14 are now being grown. Heads of representative rarieties of the different groups of barley are shown in figure 13.

TABLE XII.-Annual and average yields of 19 varielies of barley grovn in plat tests at the Juath Basin substation, Moccasin. Mont., 1908 to 1911 and 191.5 to 1915, inctusive. ${ }^{1}$

\begin{tabular}{|c|c|c|c|c|c|c|c|c|c|c|c|}
\hline \multirow{3}{*}{ Group and rariety. } & \multirow{3}{*}{$\begin{array}{l}\text { C. I. } \\
\text { Po. }\end{array}$} & \multicolumn{10}{|c|}{ Yield per acre (bushels).2 } \\
\hline & & \multirow[b]{2}{*}{$190 s$} & \multirow[b]{2}{*}{1909} & \multirow[b]{2}{*}{1910} & \multirow[b]{2}{*}{1911} & \multirow[b]{2}{*}{1913} & \multirow[b]{2}{*}{1914} & \multirow[b]{2}{*}{1915} & \multicolumn{3}{|c|}{ Aterage. } \\
\hline & & & & & & & & & $\begin{array}{l}1910 \text { to } \\
1911 . \\
1913 \text { to } \\
1915\end{array}$ & $\begin{array}{l}1913 \text { to } \\
1915\end{array}$ & $\begin{array}{l}1905 \text { to } 1911 \\
1913 \text { to } 1915\end{array}$ \\
\hline \\
\hline Canadian Thorpe... & 70 & & - & $\ldots$ & & 50.0 & 36.0 & 65.1 & & 50.3 & \\
\hline Franconian.......... & $\begin{array}{l}6 \leq 0 \\
531\end{array}$ & & & 14.4 & 45.5 & 34.3 & $\begin{array}{l}31.2 \\
46.0\end{array}$ & 90.0 & 47.9 & 39.7 & \\
\hline Hanna.............. & 678 & & & ....... & ton & 8.0 & 29.5 & -5.2 & 28.0 & & \\
\hline Mansurr............ & $61 \%$ & 20.0 & 45.7 & 13.0 & 35.3 & 457 & 35.0 & 70.5 & 41.8 & 52.5 & $3 \% .8$ \\
\hline $\begin{array}{l}\text { Sranhals............ } \\
\text { Thorpe............ }\end{array}$ & $\begin{array}{l}15 \overline{7} \\
921\end{array}$ & 10.0 & 53.3 & 1i... & $2 ; 3$ & $\begin{array}{l}4<.9 \\
52.6\end{array}$ & $\begin{array}{l}43.5 \\
39.2\end{array}$ & 65,1 & 39.6 & 53.5 & $3-4$ \\
\hline Thite smirna ..... & 195 & & & 12.3 & 52.0 & 70.0 & $50 . \overline{0}$ & so. 3 & 52.9 & 66. & $3 \ldots \frac{1}{4}$ \\
\hline \multicolumn{12}{|c|}{ Six-rowed hulled: } \\
\hline Coast .... & 690 & & & 15.0 & 43.7 & 55.0 & 43.1 & \$3. 1 & $4 \leq 0$ & 60.4 & \\
\hline $\begin{array}{l}\text { Gatami........... } \\
\text { Manchuria....... }\end{array}$ & $\begin{array}{l}575 \\
354\end{array}$ & & 45.2 & $\begin{array}{l}\text { 5. } 2 \\
9.5\end{array}$ & $\begin{array}{l}34.4 \\
40.5\end{array}$ & 39.2 & 36.0 & 32.2 & 35.6 & 42.5 & \\
\hline Mariout .............. & 251 & 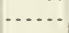 & ...... & 16.2 & 47.0 & 47.9 & 51.3 & .20 & 46.5 & $5 \div 1$ & (n...... \\
\hline \multicolumn{12}{|c|}{\begin{tabular}{l|ll|l|l}
$\ldots \ldots .2$ & 16.0 & 11.9 & 51.3 & 120 \\
$\ldots \ldots \ldots \ldots$ & $\ldots \ldots$ & 37.5 & 22.0 & $\ldots \ldots$
\end{tabular}} \\
\hline \multirow{2}{*}{\multicolumn{12}{|c|}{$\begin{array}{l}\text { McETans........ } \\
\text { Six-rowed naked: }\end{array}$}} \\
\hline $\begin{array}{l}\text { Six-roted naked: } \\
\text { Black Hull-less. }\end{array}$ & 596 & & & 13.6 & & & & & & & \\
\hline $\begin{array}{l}\text { Himalara...... } \\
\text { Tepal........ }\end{array}$ & 520 & 5.5 & 33.2 & 12.3 & 25.0 & 43.0 & 30.3 & Ax: & 31.9 & 40.7 & $2<2$ \\
\hline & & 20.0 & 42.4 & 16.7 & 30.0 & $3 \ldots 0$ & 25.7 & 71.5 & 30.2 & 34.5 & \\
\hline
\end{tabular}

1 Cron destrored by hail in 1912

2 Hulled rarieties in bushels of 4 s pounds; naked rarieties in bushels of 60 pounds. 
LEADING VARIETIES.

Table XXII shows that the White Smyrna (C. I. No. 195), with a 5-year (1910 to 1911 and 1913 to 1915) average yield of 52.9 bushels, is the leading variety. The White Smyrna is a 2-rowed hulled variety that was obtained from Asia Minor. The head is of medium length and the kernels are large. The straw is rather short, especially in a dry season, and the heads are often imperfectly exserted.

The White Smyrna is being increased at Moccasin for distribution among the farmers. About 1,200 bushels have been sold. The results obtained in other parts of the State agree with those at Moccasin, indicating that the White Smyrna is well adapted to the dry lands of Montana.

The Hannchen is a 2-rowed variety, with a narrow, nodding head, that has given good results at Moccasin. It is a selection from Hanna made by the Swedish Plant Breeding Association, of Svalof, Sweden. This variety grows a little taller than the White Smyrna and is later in maturing. The 5-year average yield of the Hannchen is about 5 bushels less than that of the White Smyrna.

The leading varieties among the 6-rowed hulled group are the Coast and the Mariout.

The Coast variety is known also as California Feed and Bay Brewing barley. It grows taller than the Mariout. The head is not as compact and the beard is not always entirely removed in thrashing. In average yield it has equaled the Hannchen, but the White Smyrna has exceeded it by about 5 bushels.

The Mariout variety has a compact spike and a rather coarse grain. As in the Coast barley, the beard sometimes is not entirely removed in thrashing. It matures about the same time as the White Smyrna. The average yield of the Mariout is slightly lower than that of the Coast variety.

The leading naked varieties of barley at Moccasin are the Nepal and Himalaya. The 5-year average yield of the Himalaya, as shown in Table XXI, is slightly greater than that of the Nepal. In the 7-year averages, however (Table XXI), the Nepal exceeds the Himalaya by 2.3 bushels. The Nepal is a 6-rowed, naked, hooded variety, sometimes called the White Hull-less. The kernels are of medium size and amber in color. The Himalaya is a 6-rowed, naked, bearded barley, with bluish kernels. Because of the absence of beards the Nepal is commonly grown in preference to the Himalaya. The heads of the Nepal have a tendency to break off when ripe, and the variety also lodges to some extent in wet years. The broad leaves, coarse straw, and absence of beards make this variety a popular one for hay production.

The average yield of the Nepal variety at Moccasin in the five years is 30.2 bushels, 20 bushels less than that of the White Smyrna during 
the same period. The weight per bushel of the naked varieties is 60 pounds, while that of the hulled varieties is 48 pounds, so that the actual difference in yield is less than would appear from these figures. The yield of the Nepal in pounds is about three-fourths that of the White Smyrna variety.

The average dates of sowing, heading, and ripening, and the average height, yield, and weight per bushel of these six varieties for five years (1910, 1911, and 1913 to 1915) are given in Table XXII. These average yields are shown graphically in figure 14 .

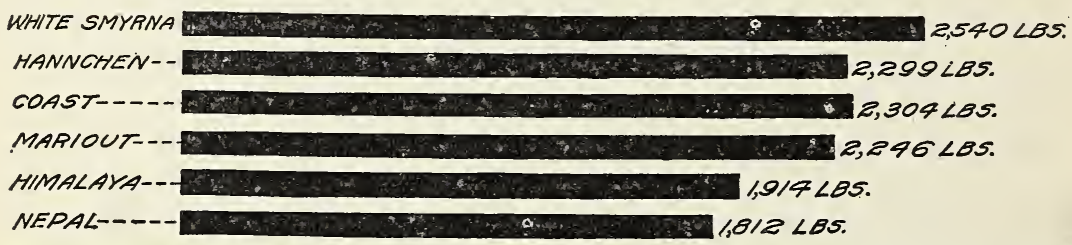

FIG. 14.-Diagram showing the average yields of the leading varieties of barley at the Judith Basin substation for five years, 1910, 1911, and 1913 to 1915, inclusive.

TABLE XXII.-Average dates of seeding, heading, and ripening, days from seeding to maturity, height, yield of straw and of grain, and weight per bushel of six leading varieties of barley at the Judith Basin substation, Moccasin, Mont., during five years, 1910, 1911, and 1913 to 1915 , inclusive.

\begin{tabular}{|c|c|c|c|c|c|c|c|c|c|c|}
\hline \multirow{2}{*}{ Group and variety. } & \multirow{2}{*}{$\begin{array}{l}\text { C. } T \text {. } \\
\text { No. }\end{array}$} & \multicolumn{3}{|c|}{ Average date- } & \multirow{2}{*}{$\begin{array}{c}\text { Seed- } \\
\text { ing to } \\
\text { ma- } \\
\text { turity. }\end{array}$} & \multirow{2}{*}{ Height. } & \multicolumn{3}{|c|}{$\begin{array}{c}\text { Average yield per } \\
\text { acre. }\end{array}$} & \multirow{2}{*}{$\begin{array}{l}\text { Weight } \\
\text { per } \\
\text { bushel. }\end{array}$} \\
\hline & & Sown. & Headed. & Ripe. & & & Grain. & Grain. & Straw. & \\
\hline $\begin{array}{l}\text { Two-rowed hulled: } \\
\text { White Smyrna. } \\
\text { Hannchen..... }\end{array}$ & $\begin{array}{l}195 \\
531\end{array}$ & $\begin{array}{c}\text { Apr. } 18 \\
\ldots \text {.do.... }\end{array}$ & $\begin{array}{lr}\text { July } & 6 \\
\text { July } & 11\end{array}$ & $\begin{array}{ll}\text { Aug. } & 4 \\
\text { Aug. } & 6\end{array}$ & $\begin{array}{r}\text { Days. } \\
108 \\
110\end{array}$ & $\begin{array}{l}\text { Inches. } \\
29 \\
32\end{array}$ & $\begin{array}{r}\text { Bush. } \\
52.9 \\
47.9\end{array}$ & $\begin{array}{l}L b s . \\
2,540 \\
2,299\end{array}$ & $\begin{array}{l}\text { Lbs. } \\
1,996 \\
2,456\end{array}$ & $\begin{array}{l}\text { Lbs. } \\
\quad 48.2 \\
49.4\end{array}$ \\
\hline $\mathrm{Cg}$ & 690 & ...d & July & Aug. 5 & 10 & 3 & & 2 , & 5 & 46.0 \\
\hline $\begin{aligned} \mathrm{Ma} \\
-\mathrm{rot}\end{aligned}$ & 261 & ...do.... & July 5 & ...do.... & 109 & 31 & 46.8 & 2,246 & 1,524 & 46.2 \\
\hline $\begin{array}{l}\text { Himalaya. } \\
\text { Nepal...... }\end{array}$ & $\begin{array}{l}620 \\
595\end{array}$ & $\begin{array}{l}\text {..do..... } \\
\text {...do..... }\end{array}$ & $\begin{array}{ll}\text { July } & 6 \\
\text { July } & 8\end{array}$ & $\begin{array}{l}\text {...do. } \\
\text {...do. }\end{array}$ & $\begin{array}{l}109 \\
109\end{array}$ & $\begin{array}{l}31 \\
32.6\end{array}$ & $\begin{array}{l}31.9 \\
30.2\end{array}$ & $\begin{array}{l}1,914 \\
1,812\end{array}$ & $\begin{array}{l}1,904 \\
1,850\end{array}$ & $\begin{array}{l}61.0 \\
61.0\end{array}$ \\
\hline
\end{tabular}

\section{EXPERIMENTS WITH FLAX.}

Experiments with flax were not started until 1911. Flax is not grown to any great extent in the Judith Basin. The crop is important in the eastern part of the State, although there is not as much flax raised now as there was several years ago. It is usually grown in newly settled districts, as it is considered a good crop to grow on sod land.

The experiments at Moccasin have included tests of both seed and fiber flax. Quite a number of fiber varieties were tested in 1911, but as they were of little value for seed production they were discarded.

\section{VARIETAL EXPERIMENTS IN FIELD PLATS.}

Nineteen varieties of flax have been grown in the rarietal test. Of these, 12 belong to the European seed, 2 to the Smyrna seed, 4 to the European short fiber, and 2 to the European textile fiber group. 
In 1911, 14 varieties were grown in twentieth-acre plats. The land used had been cropped to barley in 1909 and 1910. It was spring plowed in 1911 and the seed bed was in good tilth when the varieties were seeded on May 15. The dry weather in July caused the flax to begin to ripen early and the heavy rains in August started a second growth. This made the flax late in maturing and reduced the yields.

In 1912, 17 varieties were grown. These were seeded on May 14 in twentieth-acre plats on land that had been cropped to winter wheat the year before. Flax was the only spring grain that produced any seed in 1912, the others being destroyed by hail. The

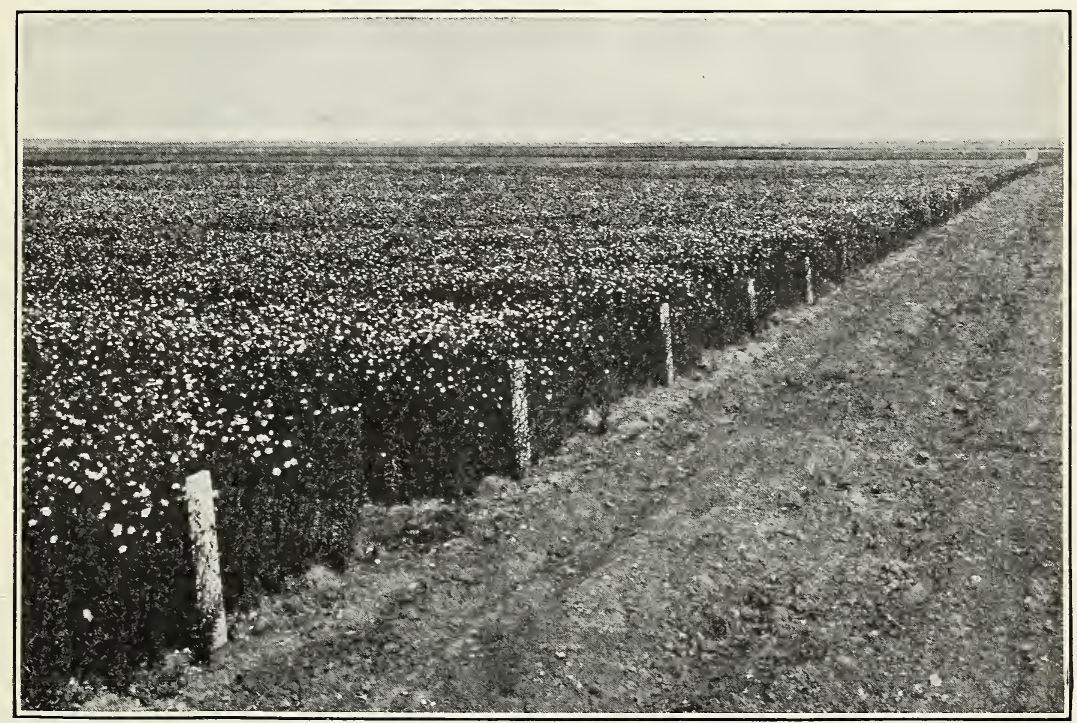

Fig. 15.-Varietal test plats of flax at the Judith Basin substation, 1915. (From a phatograph lent by the Office of Exhibits, U. S. Department of Agriculture.)

hail came when the flax was in full bloom. While it undoubtedly reduced the yields, the plants made a second growth and produced a fairly good crop. In 1913 the flax was grown in tenth-acre plats on fallow ground. The yields that year were quite satisfactory. In 1914 and 1915 the flax varieties were grown on fallow ground in replicated fiftieth-acre plats. A view of the varietal test plats in 1915 is shown in figure 15.

The yields in 1914 were reduced by a disease known as canker. This disease attacks the young plant just above the cotyledons and apparently stops its growth until it puts out basal branches below the injured part. The growth is then normal, but the time required to produce these branches makes the plants late in maturing. The seed is produced on these branches, which take the place of the central stem. 
The annual and arerage vields in bushels per acre of the rarieties of flax that hare been grown in field plats at Moccasin in the fire years, 1911 to 1915, are giren in Table XXIII.

TABLE XXIII.-Annual and average yields of 19 varieties of flax groun in plats at the Judith Basin substation, Moccasin, Mont., in periods of rarying length, 1911 to 1915. inclusive.

\begin{tabular}{|c|c|c|c|c|c|c|c|c|}
\hline \multirow{3}{*}{ Group and variets. } & \multirow{3}{*}{$\begin{array}{l}\text { C. I. } \\
\text { No. }\end{array}$} & \multicolumn{7}{|c|}{ Yield per acre (bushels). } \\
\hline & & \multirow[b]{2}{*}{1911} & \multirow[b]{2}{*}{1912} & \multirow[b]{2}{*}{1913} & \multirow[b]{2}{*}{1914} & \multirow[b]{2}{*}{1915} & \multicolumn{2}{|c|}{ Arerage. } \\
\hline & & & & & & & $\begin{array}{l}1911 \text { to } \\
1915\end{array}$ & $\begin{array}{l}1914 \text { to } \\
1915\end{array}$ \\
\hline \multicolumn{9}{|l|}{ European seed: } \\
\hline Russian (N. Dak. No. 155) & 19 & 19.3 & 13.3 & 16.6 & 13.0 & 22.5 & $1 \% .0$ & 17.9 \\
\hline Russian (N. Dak. No. 155) & 17 & 14.6 & 11. 7 & 15.6 & 12.5 & 15.9 & 14.7 & 15. \\
\hline Select Russian (N. Dak. No.60s). & 1. & 17.1 & 10.0 & 14.0 & 12.0 & 19.3 & $1 \pm .5$ & 15. \\
\hline Select Russian (N. Dak. No.609).. & 45 & & & & 13.6 & 19.0 & & 16.3 \\
\hline Select Russian (N. Dak. No. 1215) ............ & 3 & 15.7 & 13.0 & 15.0 & 12. 5 & 19.5 & 15.5 & 16. 2 \\
\hline $\begin{array}{l}\text { Jontana Common } \\
\text { Select Riga }(\mathbb{X} \text {. Dak, }\end{array}$ & $\begin{array}{l}6 \\
2\end{array}$ & $15 . \frac{1}{3}$ & $\begin{array}{r}10.0 \\
9.0\end{array}$ & $\begin{array}{r}9.0 \\
19.6\end{array}$ & $\begin{array}{l}13.2 \\
13.0\end{array}$ & 20.0 & 13.5 & 16. 6 \\
\hline Stepan (N. Dak. No.1340).................. & 5 & 15.0 & 11.3 & 16. 8 & 12. 1 & 19.9 & 15.0 & 16.0 \\
\hline North Dakota Resistant No. 52 . & 8 & 16.0 & 6.3 & 14.0 & 11. S & 19.5 & 13.7 & 15.7 \\
\hline North Dakota No. $1221 . . \ldots \ldots \ldots \ldots \ldots \ldots$. & 16 & 15. 7 & 12.7 & 16.4 & 13.2 & 19.9 & 15.6 & 16.5 \\
\hline \multirow{2}{*}{\multicolumn{9}{|c|}{ Smyrna seed: }} \\
\hline & & & & & & & & \\
\hline $\begin{array}{l}\text { Smyrna... } \\
\text { Turkish... }\end{array}$ & 30 & & & & 14.5 & 19.2 & & 17.0 \\
\hline \multirow{2}{*}{\multicolumn{9}{|c|}{ 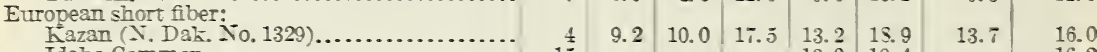 }} \\
\hline & $\underline{4}$ & 9.2 & 10.0 & 17.5 & 13.2 & 15.9 & 13.7 & 16.0 \\
\hline 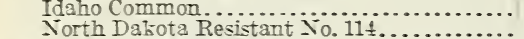 & $\begin{array}{l}15 \\
13\end{array}$ & & & & $\begin{array}{l}13.0 \\
12.3\end{array}$ & $\begin{array}{l}19.4 \\
16.8\end{array}$ & …...... & $\begin{array}{ll}16 . \\
1 \downarrow .\end{array}$ \\
\hline 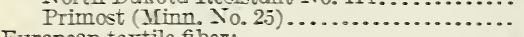 & 12 & 11.0 & 10.3 & 17.5 & 12.8 & 19.1 & 141 & 16.0 \\
\hline \multicolumn{9}{|l|}{ European textile fiber: } \\
\hline Pskof...... & 32 & & & - & 10.0 & S. 0 & 10.0 & 9.0 \\
\hline
\end{tabular}

LEADING VARIETIES.

Table XXIII shows that in both the 5-rear and 2-rear arerages the rarieties of the European seed-flax group vield more than those of the other groups. The fire highest rielding strains for the 5 -year period, C. I. Nos. 19, 3, 2, 16, and 1S, all belong to the seedflax group. The Russian, C. I. No. 19 (N. Dak. No. 155), is the highest yielder and the Select Russian, C. I. No. 3 (N. Dak. No. 1213), a selection from North Dakota No. 155, is second. C. I. Nos. 17 and 19 are both Russian (N. Dak. No. 155), but were receired at Moccasin through different sources. C. I. No. 19 has giren better results than C. I. No. 17. North Dakota No. 155 is a bulk lot of seed of Russian flax obtained by the North Dakota Agricultural Experiment Station in 189S. It has been grown and distributed since that time. C. I. Nos. 1, 3, and 45 are selections from this rariety dereloped in the nursery at the North Dakota station.

C. I. Nos. 2 and 16 were both dereloped through selection from common flax rarieties at the North Dakota station, while C. I. No. 18 was a bulk lot of seed obtained br that station in 1901 from a seed house at Fargo, N. Dak. All of these strains are of the Russian seed type of flax, and with the exception of some rariations in coarseness of stem and earliness are much alike. 
North Dakota Resistant No. 52, a wilt-resistant flax of the seed type, has not yielded as well as the Russian.

The Smyrna flax (C. I. No. 30), which ranks second in average yield for the two years it has been grown, was imported from Smyrna, Turkey, by the United States Department of Agriculture, in 1913. This variety has shorter straw and more numerous basal branches than the European seed flaxes. From results obtained elsewhere it seems to be better able to withstand unfarorable hot, dry weather than other varieties in the test.

North Dakota Resistant No. 114 and Primost (Minn. No. 25), both of which belong to the short-fiber group, did not produce yields which compare farorably with those of the European seed flaxes. These varieties would probably give better results in regions where flax canker is more serious than at Moccasin.

The textile fiber type of flax is of no value for seed production in Montana.

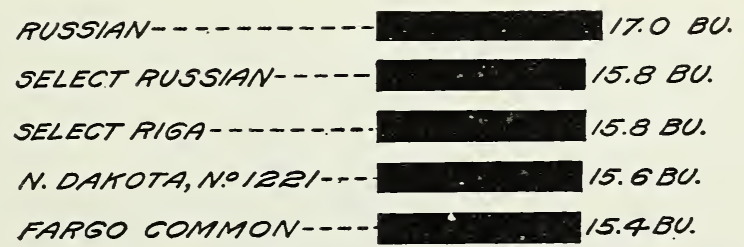

FIG. 16.-Diagram showing the average yields (in bushels per acre) of the leading varieties of flax at the Judith Basin substation for the five years, 1911 to 1915 , inclusive.

Table XXIV gives the average dates of seeding, heading, and ripening, the yields of straw and grain, and the weight per bushel of the five leading varieties of flax in the five years 1911 to 1915, inclusive. The average yields of these varieties are shown graphically in figure 16 .

TABLE XXIY.-Average dates of seeding, heading, and ripening, days from seeding to maturity, yield of grain and straw, and weight per bushel of five leading flax varieties at the Judith Basin substation, Moccasin, Mont., in the five years, 1911 to 1915, inclusive.

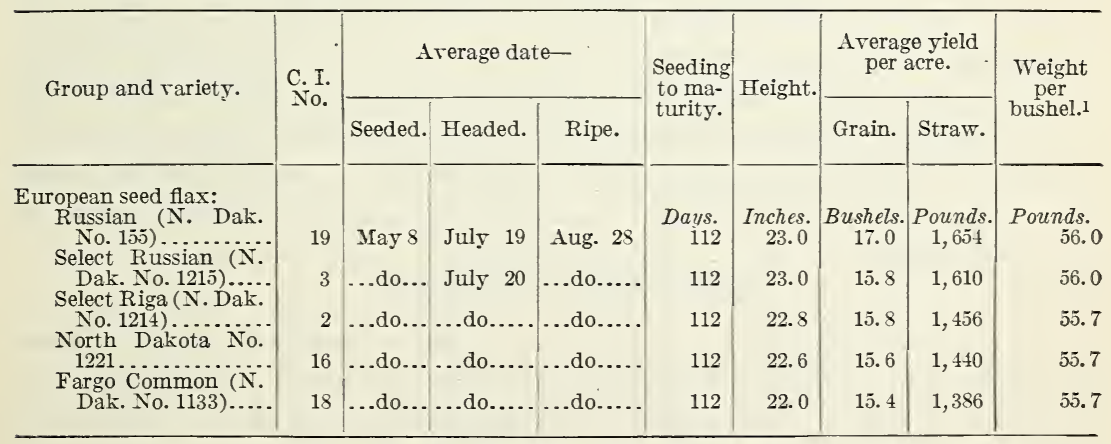

${ }^{1}$ Average for four years, 1912 to 1915, inclusive. 
VARIETAL EXPERIMENTS IN NURSERY ROWS.

Nursery work with flax was not started until 1914, when 50 varieties and strains were tested. These varieties were grown in fiftiethacre and hundredth-acre plats and in 8-rod rows. Most of them were recent importations from Europe which were grown in this country for the first time in 1914.

In 1915 the flax nursery was increased. In addition to the tests in fiftieth-acre plats and 8-rod rows, 204 selections were grown in head rows. Some of the head rows were selections from the most promising varieties and some were selections from a natural hybrid. A view of the flax nursery in 1915 is shown in figure 17 .

Several promising varieties which are now being grown in the nursery will soon be added to the varietal test.

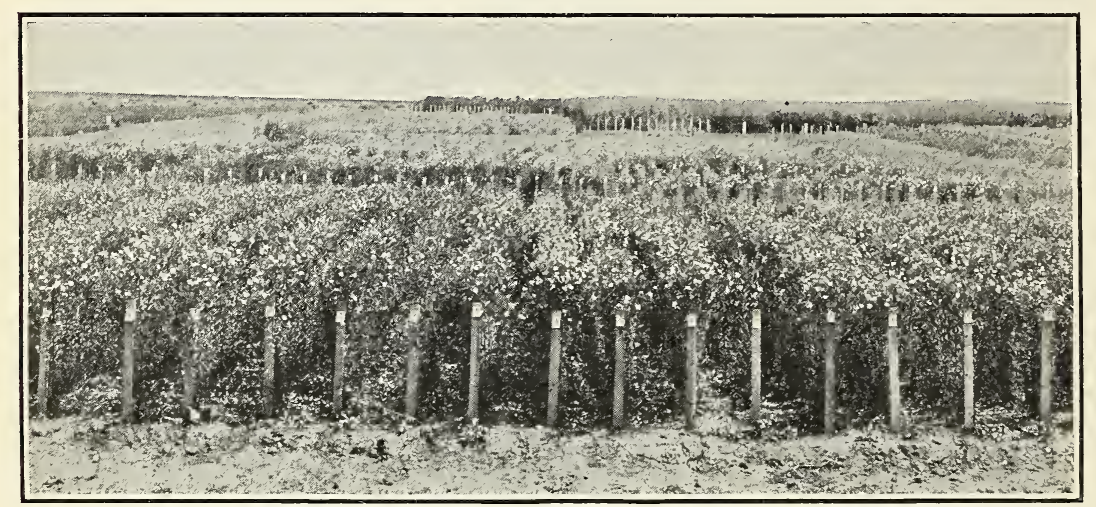

Fig.17.-The flax nursery at the Judith Basin substation, 1915. (From a photograph lent by the Office of Exhibits, U. S. Department of Agriculture.)

DATE-OF-SEEDING EXPERIMENT.

There appears to be some question as to the proper date on which to sow flax. The impression seems to exist in some sections that flax should be sown later than the spring grains. The date-of-seeding test at Moccasin has not been conducted long enough to justify drawing definite conclusions from it. The results seem to indicate, however, that early seeding is the best. In 1915 the highest yield was obtained from the plat seeded on April 9. While there was some freezing weather after this date it apparently did no harm to the flax. The tests at Moccasin show that flax should be sown not later than May 1, as seedings made after that date will not produce as good yields.

\section{RATE-OF-SEEDING EXPERIMENT.}

A rate-of-seeding test with flax is being conducted at Moccasin, but, like the date-of-seeding test, it has not been continued long enough to justify any definite conclusions. During the last three years the varietal plats have been seeded at the rate of 18 pounds 
per acre. Very satisfactory stands and yields have been obtained from this rate, although the rate-of-seeding experiment seems to indicate that a little heavier seeding would give better results.

\section{COMPARISON OF THE LEADING VARIETIES OF CEREALS.}

Table XXV gives the annual and average yields (in pounds per acre) of the leading varieties of each of the cereals at Moccasin for five years, 1910, 1911, and 1913 to 1915, inclusive. This table is presented so that a comparison may be made of the actual yield of grain of each of the cereals. It will be seen from Table XXV that on the average the White Smyrna barley produces more pounds of grain per acre than any of the other cereals. The Kharkof winter wheat is second and the Sixty-Day oats third in the number of pounds of grain produced per acre.

The average farm value per acre of each of the crops is also given in Table XXV. To obtain this value the annual yield of each crop was multiplied by the farm price per bushel in Montana on December 1 of that year, and the annual values for the five years were then averaged. Winter wheat leads in value per acre, with the White Smyrna barley second and flax third.

TABLE XXV.-Annual and average yields and average farm value of the leading variety of each of the cereals grown at the Judith Basin substation. Moccasin, Mont., for five years 1910,1911, and 1913 to 1915, inclusive.

\begin{tabular}{|c|c|c|c|c|c|c|c|c|}
\hline \multirow{2}{*}{ Crop and variety. } & \multirow{2}{*}{$\begin{array}{l}\text { C. I. } \\
\text { No. }\end{array}$} & \multicolumn{6}{|c|}{ Yield per acre (pounds). } & \multirow{2}{*}{$\begin{array}{l}\text { Acre } \\
\text { value of } \\
\text { crop }\end{array}$} \\
\hline & & 1910 & 1911 & 1913 & 1914 & 1915 & $\begin{array}{l}\text { A ver- } \\
\text { age. }\end{array}$ & \\
\hline 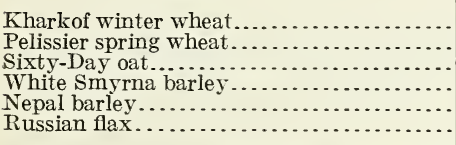 & $\begin{array}{r}1,583 \\
1,584 \\
165 \\
195 \\
595 \\
19\end{array}$ & $\begin{array}{r}2,880 \\
630 \\
1,056 \\
590 \\
984 \\
\end{array}$ & $\begin{array}{l}2,478 \\
1,698 \\
2,278 \\
2,490 \\
1,800 \\
1,070\end{array}$ & $\begin{array}{r}1,866 \\
1,920 \\
2,409 \\
3,360 \\
2,220 \\
930\end{array}$ & $\begin{array}{r}1,470 \\
1,590 \\
1,888 \\
2,400 \\
1,542 \\
728\end{array}$ & $\begin{array}{l}2,964 \\
2,530 \\
2,998 \\
3,854 \\
2,508 \\
1,282\end{array}$ & $\begin{array}{l}2,331 \\
1,673 \\
2,126 \\
2,540 \\
1,810 \\
1,002\end{array}$ & $\begin{array}{r}\$ 31.08 \\
21.58 \\
23.70 \\
28.42 \\
18.24 \\
a 27.09\end{array}$ \\
\hline
\end{tabular}

a Average for four years, 1911 and 1913 to 1915.

\section{EXPERIMENTS WITH MINOR CEREALS.}

Twenty-seven varieties of proso have been tested at Moccasin at some time during the past eight years. While most of the varieties tried will mature seed in a favorable year, the yield is small and in some years no seed is produced. For this reason the crop is not recommended for the Judith Basin.

Some early varieties of brown kaoliang and broom corn were tried for three years. Owing to the short season and cool nights none of them matured seed.

Emmer and spelt have also been tried, but are not as promising as some of the other grain crops. 


\section{SLMMARY.}

Cooperative experiments with cereals at the Judith Basin substation. Moccasin. Mont.. hare been conducted during eight rears; 1908 to 1915 . inclusire.

The Judith Basin substation is located in the rest-central part of Fergus County. in central Montana. The altitude is 4.300 feet.

The rields obtained at Moccasin are not representatire of all the drr-land area. but the comparatire results obtained are beliered to be applicable in general to all the dry-farming area of Montana.

The annual arerage precipitation at Moccasin for 18 rears, 1595 to 1915. inclusire. is 16.66 inches. The arerage seasonal rainfall April to Tulr. inclusive for the same rears is 9.11 inches.

The soil at Moccasin on which the cereal rarieties hare been tested is a dark clar loam of limestone origin.

On the arerage. satisfactor rields are obtained from winter and spring wheat. spring oats. barler, and flax.

The best winter wheats are the Kharkof and Turker. These belong to the Crimean group of hard winter wheats.

The best rate to sow winter wheat is 3 pecks per acre. The best. date to sow is from August 10 to September 10.

The highest rields of spring wheats hare been obtained from rarieties of durum wheat. Of these, the Pelissier has been the best. Of the common spring wheats the best rariety to grow appears to be the Marquis.

Spring wheats are seeded at the rate of 1 pecks per acre.

The best results are obtained from sowing all spring wheat, oats. and barler as earls in the spring as soil and climatic conditions will permit.

The highest aremge rield of oats was obtained from the Sixty-Day rariety. This rariets areraged about 16 bushels per acre more than later maturing rarieties.

The best rate of seeding for the small-herneled early rarieties of oats, such as the Sixty-Dar. is about 4 pechs per acre.

The Thite smrma barley. a 2-rowed bearded hulled rarietr, has giren the highest arerage rield.

The hulled rarieties of barler are seeded at the rate of 5 pechs and the naked rarieties at the rate of \pm pechs per acre.

The highest rield of flax in a 5-rear test mas obtained from the Russian rariety.

It is probable that the best results will be obtained if flax is sown earls. between April 15 and Mar 1 . The best rate seems to be fron 20 to 25 pounds per acre.

In pounds per acre, the arerage rield of the White Smrrna barley is greater than that of the best rariety of any of the other cereal 
crops. The Kharkof winter wheat is second in yield, followed by the Sixty-Day oats, the Nepal naked barley, the Pelissier spring wheat, and the Russian flax.

In the value per acre based on the farm price on December 1 of each year, the Kharkof winter wheat leads, followed by the White Smyrna barley, the Russian flax, the Sixty-Day oats, the Pelissier durum spring wheat, and the Nepal naked barley.

Emmer and spelt do not give as good yields as barley and oats.

Proso millet has been tried, but is not a promising crop.

Early varieties of brown kaoliang and broom corn have been tested, but do not mature seed. 


\section{PUBLICATIONS OF U. S. DEPARTMENT OF AGRICULTURE TREATING OF CEREAL PRODUCTION IN THE NORTHERN GREAT PLAINS.}

\section{AVAILABLE FOR FREE DISTRIBUTION BY DEPARTMENT OF AGRICULTURE.}

Cereal Experiments at Dickinson, N. Dak. Department Bulletin 33.

Spring Wheat in the Great Plains Area: Relation of Cultural Methods to Production. Department Bulletin 214.

Oats in the Great Plains Area: Relation of Cultural Methods to Production. Department Bulletin 218.

Barley in the Great Plains Area: Relation of Cultural Methods to Production. Department Bulletin 222.

Crop Production in the Great Plains Area: Relation of Cultural Methods to Yields. Department Bulletin 268.

Cereal Experiments at the Williston Substation. Department Bulletin 270.

Cereal Investigations on the Belle Fourche Experiment Farm. Department Bulletin 297 .

Alaska and Stoner, or "Miracle," Wheats: Two Varieties Much Misrepresented. Department Bulletin 357.

Oats: Distribution and Uses. Farmers' Bulletin 420.

Oats: Growing the Crop. Farmers' Bulletin 424.

Barley: Growing the Crop. Farmers' Bulletin 443.

The Smuts of Wheat, Oats, Barley, and Corn. Farmers' Bulletin 507.

Durum Wheat. Farmers' Bulletin 534.

Growing Hard Spring Theat. Farmers' Bulletin 678.

Varieties of Hard Spring Wheat. Farmers' Bulletin 680 .

Marquis Wheat. Farmers' Bulletin 732.

Grains for the Montana Dry Lands. Farmers' Bulletin 749.

Winter Wheat in Western South Dakota. Bureau of Plant Industry Circular 79.

Hard Wheats Winning Their Way. Separate 649, Yearbook, 1914.

\section{FOR SALE BY THE SUPERINTENDENT OF DOCUMENTS, GOVERNMENT PRINTING} OFFICE, WASHINGTON, D. C.

Experiments with Wheat, Oats, and Barley in South Dakota. Department Bulletin 39. Price, 10 cents.

The Commercial Status of Durum Wheat. Bureau of Plant Industry Bulletin 70 . Price, 10 cents.

Improving the Quality of Wheat. Bureau of Plant Industry Bulletin 78. Price, 10 cents.

The Loose Smuts of Barley and Wheat. Bureau of Plant Industry Bulletin 152. Price, 15 cents.

Dry-Land Grains for Western North and South Dakota. Bureau of Plant Industry Circular 59. Price, 5 cents. 